\title{
Desiccation time and rainfall control gaseous carbon fluxes in an intermittent stream
}

\author{
Maria Isabel Arce (iD) Mia M. Bengtsson (iD) - Daniel von Schiller (D) \\ Dominik Zak (1) · Jana Täumer (D) Tim Urich (1) $\cdot$ Gabriel Singer $(1)$
}

Received: 17 March 2021 / Accepted: 29 June 2021 / Published online: 23 July 2021

(C) The Author(s) 2021

\begin{abstract}
Droughts are recognized to impact global biogeochemical cycles. However, the implication of desiccation on in-stream carbon (C) cycling is not well understood yet. We subjected sediments from a lowland, organic rich intermittent stream to experimental desiccation over a 9-week-period to investigate temporal changes in microbial functional traits in relation to their redox requirements, carbon dioxide $\left(\mathrm{CO}_{2}\right)$ and methane $\left(\mathrm{CH}_{4}\right)$ fluxes and water-soluble organic carbon (WSOC). Concurrently, the implications of rewetting by simulated short rainfalls (4 and $21 \mathrm{~mm}$ ) on gaseous $\mathrm{C}$ fluxes were tested. Early desiccation triggered dynamic fluxes of $\mathrm{CO}_{2}$ and $\mathrm{CH}_{4}$ with peak values of 383 and $30 \mathrm{mg} \mathrm{C} \mathrm{m} \mathrm{m}^{-2} \mathrm{~h}^{-1}$ (mean $\pm \mathrm{SD}$ ), respectively, likely in response to enhanced aerobic mineralization and accelerated
\end{abstract}

Responsible Editor: Jennifer Leah Tank.

M. I. Arce $(\bowtie) \cdot D$. Zak · G. Singer

Leibniz-Institute of Freshwater Ecology and Inland Fisheries (IGB), Berlin, Germany

e-mail: marisarce@um.es

Present Address:

M. I. Arce

Department of Ecology and Hydrology, Campus of International Excellence "Campus Mare Nostrum", University of Murcia, Murcia, Spain

M. M. Bengtsson · J. Täumer · T. Urich Institute of Microbiology, University of Greifswald, Greifswald, Germany evasion. At longer desiccation, $\mathrm{CH}_{4}$ dropped abruptly, likely because of reduced abundance of anaerobic microbial traits. The $\mathrm{CO}_{2}$ fluxes ceased later, suggesting aerobic activity was constrained only by extended desiccation over time. We found that rainfall boosted fluxes of $\mathrm{CO}_{2}$, which were modulated by rainfall size and the preceding desiccation time. Desiccation also reduced the amount of WSOC and the proportion of labile compounds leaching from sediment. It remains questionable to which extent changes of the sediment $\mathrm{C}$ pool are influenced by respiration processes, microbial $\mathrm{C}$ uptake and cell lysis due to dryingrewetting cycles. We highlight that the severity of the dry period, which is controlled by its duration and the presence of precipitation events, needs detailed consideration to estimate the impact of intermittent flow on global riverine $\mathrm{C}$ fluxes.

D. von Schiller

Department of Evolutionary Biology, Ecology and Environmental Sciences, Institut de Recerca de l'Aigua (IdRA), University of Barcelona, Barcelona, Spain

D. Zak

Department of Bioscience, Aarhus University, Silkeborg, Denmark

G. Singer

Department of Ecology, University of Innsbruck, Innsbruck, Austria 
Keywords Carbon dioxide - Methane - WSOC · Leaching $\cdot$ Dry riverbeds $\cdot$ Rewetting

\section{Introduction}

Streams play a substantial role in global carbon (C) cycling by releasing carbon dioxide $\left(\mathrm{CO}_{2}\right)$ and methane $\left(\mathrm{CH}_{4}\right)$ to the atmosphere and by shaping the quantity and quality of dissolved organic $\mathrm{C}$ through organic matter processing during its transit towards the ocean (Raymond et al. 2016). Uncertainties still exist on $\mathrm{C}$ fluxes in streams that suffer from discontinuities in flow. Over $50 \%$ of the global stream network is intermittent, experiencing flow cessation and drying at some points in space and time (Acuña et al. 2014). The frequency, duration and magnitude of intermittency are expected to dramatically increase in response to climate change and growing water use (Messager et al. 2021). In arid and semiarid regions, intermittent streams are the dominant surface water type (Datry et al. 2014). Regions that are more humid are no exception, however, and numerous temperate lowland streams are increasingly experiencing hydrological drought (Andersen et al. 2006; Nützmann and Mey 2007); yet, the impact of flow intermittency on biogeochemical cycles has been poorly addressed (Dewey et al. 2020).

Recent research suggests that the dry reaches of intermittent streams, which are typically excluded from global $\mathrm{C}$ budgets, can contribute significantly to global gaseous $\mathrm{CO}_{2}$ fluxes from stream networks to the atmosphere (Marcé et al. 2019; Keller et al. 2020). Beyond the dry phase, intermittent streams can supply $\mathrm{C}$ to other downstream ecosystems through leachates from dry substrates upon rewetting (Shumilova et al. 2019). Compared with streams in arid and semiarid areas, lowland streams in temperate climate regions tend to accumulate larger amounts of organic matter; thus, understanding how dry-wet cycles alter $\mathrm{C}$ turnover is essential to anticipate environmental consequences of drying in stream networks.

The duration of the dry period, seen as a proxy of desiccation severity, is recognized to greatly shape biogeochemical cycling in intermittent streams (Muñoz et al. 2018; Arce et al. 2019; Vidal-Abarca et al. 2020). Desiccation induces changes in the structure and functioning of microbial communities
(Febria et al. 2012; Romaní et al. 2017) and in the physico-chemical conditions of sediments (von Schiller et al. 2017; Casas-Ruiz et al. 2016; Harjung et al. 2019a). As redox requirements are fundamental in defining microbial niches, turnover in the microbial community may be expected, with ensuing implications for $\mathrm{C}$ cycling and gaseous $\mathrm{C}$ fluxes. Besides, biogeochemical implications of desiccation can be locally noted at vertical scale in sediments, with surface sediments being generally more susceptible to drying than deeper, more desiccation-protected layers (Arce et al. 2019). Exposure to air diminishes the activity of anaerobic functional groups, including $\mathrm{CH}_{4}$-producing methanogens, especially in surface sediments. Conversely, the activity of aerobic microbes like $\mathrm{CH}_{4}$-oxidizers (i.e., methanotrophs) may remain unchanged as long as $\mathrm{CH}_{4}$ is available. Correspondingly, low $\mathrm{CH}_{4}$ but high $\mathrm{CO}_{2}$ fluxes have been reported from dry reaches of intermittent streams (von Schiller et al. 2014; Gómez-Gener et al. 2015, 2016).

Increased $\mathrm{CO}_{2}$ fluxes are attributed to favored growth of aerobic heterotrophic microbes during oxygen-rich desiccation periods (Fromin et al. 2010). However, persisting desiccation both in aquatic sediments and soils is known to impact microbial community structure and activity and to limit diffusion and supply of dissolved nutrients (Romaní et al. 2017; Schimel 2018). This may result in the cessation of evasion of biogenic (i.e. microbially produced) gases (Arce et al. 2019; Marcé et al. 2019). In soils, nutrient and $\mathrm{C}$ processing, specifically $\mathrm{CO}_{2}$ fluxes, tend to rapidly increase in response to rewetting, a phenomenon known as "Birch effect" (Birch 1958; Kim et al. 2012); relatively less studied in dry riverbed sediments (Arce et al. 2019; Marcé et al. 2019; von Schiller et al. 2019). Rain-induced rewetting during the dry period without generating surface flow may trigger temporarily high $\mathrm{C}$ fluxes to the atmosphere despite streams appearing as seemingly quiescent because of the lack of surface water. For instance, Gallo et al. (2014) observed increased fluxes of $\mathrm{CO}_{2}$, $\mathrm{CH}_{4}$ and $\mathrm{N}_{2} \mathrm{O}$ following simulated rainfalls in several dry ephemeral streams in Arizona, USA. Furthermore, the size of the rainfall and the duration of the precedent desiccation period can shape the magnitude of rainfallinduced gas fluxes (Arce et al. 2018; Gebremichael et al. 2019). 
Since a surface water compartment providing nutrients and $\mathrm{C}$ is not available during desiccation, streambed sediments gain importance as a source of substrates fueling the short-term $\mathrm{C}$ fluxes to atmosphere. Furthermore, while short rainfall can impact $\mathrm{C}$ fluxes to atmosphere, organic $\mathrm{C}$ stocks in sediments can also be mobilized and exported to downstream reaches only upon a more intense rewetting.

Yet, there are large uncertainties regarding the effects of desiccation on water-soluble organic $\mathrm{C}$ (WSOC), an important fraction of $\mathrm{C}$ stored in sediments (Tao and Lin 2000). Understanding changes in the quantity and quality of WSOC leaching from dry streambed sediments is fundamental to appraise the quality of stream water once water flow recovers (Shumilova et al. 2019). Biotic and abiotic transformations, such as respiration and microbial leaching due to dry-wet osmotic shifts (Fellman et al. 2011; Vázquez et al. 2011; Ylla et al. 2011) can alter the quantity and composition of WSOC (Dahm 1981; McMaster and Bond 2008; Sabater and Tockner 2010). In intermittent stream networks, fluxes of the released elements upon flow resumption may exceed baseflow values by several orders of magnitude. Thus, these fluxes can substantially contribute to annual catchment export (Skoulikidis and Amaxidis 2009; Bernal et al. 2013).

This study addresses two main objectives. First, we investigate changes of in-stream $\mathrm{C}$ gaseous fluxes $\left(\mathrm{CO}_{2}\right.$ and $\mathrm{CH}_{4}$ emissions to atmosphere) and WSOC leached from sediments, as desiccation progresses in time. Second, we explore the implications of short rainfall events of variable size (4 and $21 \mathrm{~mm})$ on gaseous $\mathrm{C}$ fluxes to the atmosphere in dependence of the precedent desiccation time. We predict that temporal progression of desiccation will drive rapid and substantial changes in the fluxes of $\mathrm{CO}_{2}$ and $\mathrm{CH}_{4}$ from sediments to the atmosphere primarily because of shifts in water and oxygen availability. More specifically, we expect an increase in the flux of $\mathrm{CO}_{2}$ and a decrease in the flux of $\mathrm{CH}_{4}$ over desiccation time. Furthermore, physicochemical changes in sediments will shape the abundance of microbial functional traits based on redox requirements (aerobic vs. anaerobic taxa), especially in surface sediments, and will impact microbial $\mathrm{C}$ production due to water stress. Over progressing desiccation time, altered C-transformations will imprint on the quantity and quality of WSOC leached from sediments.
Considering that longer desiccation induces microbial stress but water can alleviate this stress, we also predict that rainfall-induced rewetting will boost gaseous $\mathrm{C}$ fluxes. However, this response will be stronger the higher the amount of rewetting water, and weaker the longer the precedent desiccation time.

\section{Methods}

Experimental design

Water and submerged sediments were collected from the Fredersdorfer Mühlenfließ, a temperate, intermittent, lowland stream located in Brandenburg, southeast of Berlin (North Germany, 52 $26^{\circ}$ 27.51' $\mathrm{N}$; $13^{\circ} 41^{\prime} 00.85^{\prime}$ ' E, $38 \mathrm{~m}$ asl). The catchment size of the $32.6-\mathrm{km}$ long stream is $230 \mathrm{~km}^{2}$. The stream channel is typically colonized by Ranunculion fluitantis and Callitricho-Batrachion alliances and floating aquatic mosses (Natura 2000 habitat type 3260). The riparian zone consists of a mosaic of calcareous open peatlands, grasslands and natural floodplain forests with Alnus glutinosa und Fraxinus excelsior. Sampling was done at the end of May 2015 before surface flow declined. Nutrient and $\mathrm{C}$ concentrations in surface water (mean $\pm \mathrm{SD}, \mathrm{n}=3$ ) were $230 \pm 25 \mu \mathrm{g} \mathrm{N} \mathrm{L}^{-1}$ for $\mathrm{NO}_{3}{ }^{-}, 360 \pm 50 \mu \mathrm{g} \mathrm{N} \mathrm{L}^{-1}$ for $\mathrm{NH}_{4}{ }^{+}, 31 \pm 2 \mu \mathrm{g} \mathrm{P}$ $\mathrm{L}^{-1}$ for soluble reactive phosphorus, $10.6 \pm 1.5 \mathrm{mg} \mathrm{C}$ $\mathrm{L}^{-1}$ for dissolved organic carbon (DOC), and $0.53 \pm 0.21 \mathrm{mg} \mathrm{N} \mathrm{L}^{-1}$ for dissolved organic nitrogen (DON).

Sediment samples were collected at 3 different sites along a $100 \mathrm{~m}$-reach, sieved ( $4 \mathrm{~mm}$ mesh size), and transported to the laboratory. In the laboratory, 30 transparent acrylic glass columns (length $30 \mathrm{~cm}$, diameter $5.5 \mathrm{~cm}$ ) were filled with sediments to a depth of $15 \mathrm{~cm}$ and stream water to completely wet them with a $2-3 \mathrm{~cm}$ surface water layer. Ten microcosms were each filled with sediment from one of the three field sites so that the 3 lab replicates sampled destructively at later time points always represented field replicates. All 30 microcosms were closed at the bottom with a gas- and water-tight plug fitted with a drainage and a stopcock, and placed in a ventilated climate chamber $\left(25^{\circ} \mathrm{C}\right.$, dark $)$. After 1 week of acclimation, 3 replicate microcosms were destructively sampled for initial, wet conditions (pre-desiccation conditions or $\mathrm{t}=0$ weeks) (Fig. 1). Such pre- 


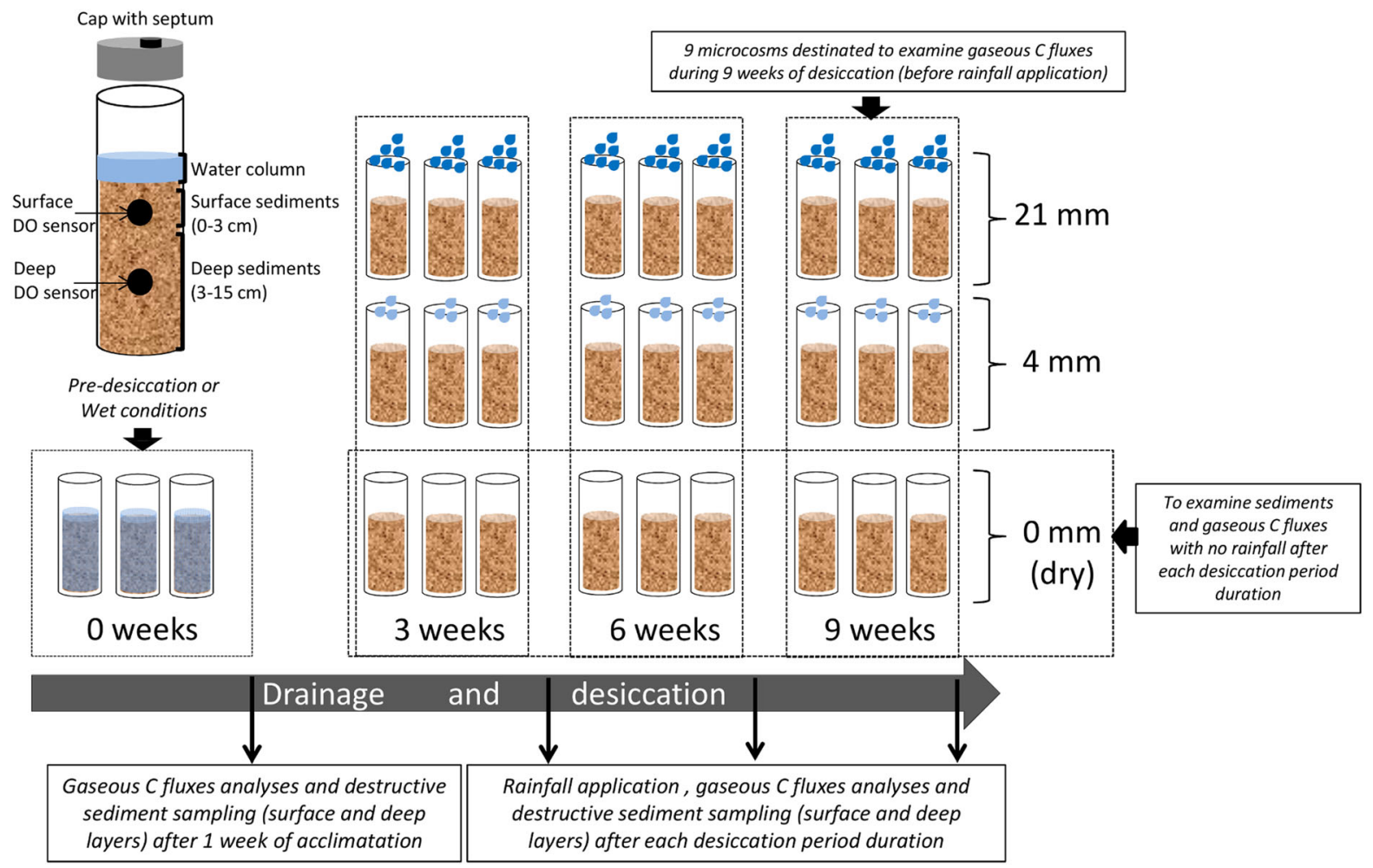

Fig. 1 Experimental design

desiccation conditions hydrologically simulate a pool environment, which typically occurs during stream fragmentation before desiccation (von Schiller et al. 2017). The remaining 27 microcosms were grouped in 3 sets of 9 microcosms desiccated by drainage over 3 , 6 or 9 weeks. Desiccation was achieved by draining water through the bottom outlets until the whole overlaying water in the microcosms vanished (approx. $24 \mathrm{~h}$ ) and by evaporation in the ventilated climate chamber; this simulated a losing intermittent reach, which is subjected to desiccation by loss of water through the hyporheic zone to groundwater (Boulton et al. 2017). After each desiccation period (3, 6 and 9 weeks), different rainfall size was simulated, namely 0 (dry), 4 and $21 \mathrm{~mm}$ (Fig. 1), by spraying artificial rainwater mimicking local rain chemistry $\left(1.4 \mathrm{mg} \mathrm{L}^{-1}\right.$ of $\mathrm{Cl}^{-}, 2.2 \mathrm{mg} \mathrm{L}^{-1}$ of $\mathrm{SO}_{4}{ }^{2-}, 0.4 \mathrm{mg} \mathrm{L}^{-1}$ of $\mathrm{K}^{+}$and $1.6 \mathrm{mg} \mathrm{L}^{-1}$ of $\mathrm{Ca}^{2+}$ ). The different rainfalls just differed in the amount of water added over the microcosms, being duration and intensity of application the same. After gas collection, the dry treatment (i.e. $0 \mathrm{~mm}$ ) set was destructively sampled with the purpose of studying biogeochemical and microbial parameters in two depth layers over desiccation time. The 4 and $21 \mathrm{~mm}$ - treatment sets were similarly sampled after the simulated rainfalls to characterize the percentage of water content (WC\%) in two sediment depth layers. Gaseous C fluxes were determined throughout the whole experiment from microcosms set aside for sampling after 9 weeks of desiccation. This set was also employed to monitor the variation in $\mathrm{WC} \%$ in the whole sediment column via change in microcosm weight, and the dissolved oxygen (DO) in the interstitial surface and deep sediments (Fig. 1). For that, we used optode sensors (circular, diameter $0.5 \mathrm{~cm}$ ) attached on the inner walls at depths of 2 and $9 \mathrm{~cm}$, respectively, and a Fiber Optic Oxygen Meter Microx4 (PreSens, Regensburg, Germany).

\section{Gaseous C fluxes}

To study $\mathrm{CO}_{2}$ and $\mathrm{CH}_{4}$ fluxes, we collected 2-3 gas samples from microcosms closed by a gas-tight plug fitted with a septum over $1 \mathrm{~h}$ to compute concentration changes. To study desiccation effects, this was done in 
9 microcosms before eventual rainfall-treatment throughout 9 weeks of desiccation (Fig. 1): before drainage, when microcosms had a water table $(t=-3$ days), immediately after ( $\mathrm{t}=0$ days $)$ and several days after drainage ( $\mathrm{t}=3,6,11,17,27,39,52$ and 62 days).

To study short-term effects of rainfall events, 5 monitoring times were established: before $(t=-2 h)$, immediately $(\mathrm{t}=0 \mathrm{~h})$ and three times after rainfall treatment $(\mathrm{t}=2,6$ and $24 \mathrm{~h})$. In all cases, headspace gas samples $(1 \mathrm{~mL})$ were directly injected into a Los Gatos ultraportable GHG analyzer (San José, CA, USA) for $\mathrm{CH}_{4}$ and $\mathrm{CO}_{2}$ measurements (Wilkinson et al. 2018). All measured concentrations were converted to mass units through the application of the Ideal Gas Law:

$n=(P \cdot V) /(R \cdot T)$

where $n$ is the number of moles/volume concentration (e.g. moles $\mathrm{C}-\mathrm{CO}_{2} \mathrm{~L}^{-1}$ enclosure), $P$ is the barometric pressure, $V$ is the volume/volume concentration (trace gas concentration expressed in ppmv or $\mu \mathrm{L} \mathrm{C- \textrm {CO } _ { 2 }}$ $\left.\mathrm{L}^{-1}\right), R$ is the universal gas constant $(0.0820575 \mathrm{~L}$ atm $\mathrm{K}^{-1} \mathrm{~mol}^{-1}$ ), and $T$ is the air temperature expressed in $\mathrm{K}$. By using the molecular weight of the trace gas species (e.g. $12 \mu \mathrm{g} \mathrm{C}-\mathrm{CO}_{2}$ per $\mu \mathrm{mol} \mathrm{CO}_{2}$ ) the number of moles were converted to concentration values $\left(C_{m}\right)$. They were then used to calculate gaseous fluxes via linear regression of headspace gas concentration versus time elapsed since the plug placement and considering microcosm headspace and the sediment area by means of the following equation:

$f=\left(\Delta C_{m} / \Delta t \cdot V_{h s}\right) / A$,

where $f$ is gas flux as mass of $\mathrm{C}$ as $\mathrm{CO}_{2}$ or $\mathrm{CH}_{4}$ per area and time expressed as $\mathrm{mg} \mathrm{C} \mathrm{m}{ }^{-2} \mathrm{~h}^{-1}, \Delta C_{m} / \Delta t$ is the change in concentration of gas $\left(C_{m}\right)$ over the enclosure period time expressed as $\mathrm{mg} \mathrm{C} \mathrm{m}{ }^{-3} \mathrm{~h}^{-1}, V_{h s}$ is internal volume of the headspace expressed as $\mathrm{m}^{3}$, and $A$ is the sediment area expressed as $\mathrm{m}^{2}$. Additionally, the total or cumulative gas flux post rainfall (mg C $\mathrm{m}^{-2}$ ) was calculated by integrating the fluxes over $24 \mathrm{~h}$ following the moment of simulated rainfall.

Sediment sampling, water content and organic matter properties

Subsequent to gas sampling, sediments of the dry microcosms (i.e. rainfall $=0 \mathrm{~mm}$ ) were destructively sampled at the surface $(0-3 \mathrm{~cm})$ and deep layers
$(3-15 \mathrm{~cm})$ to determine water content. Immediately after sampling, $1 \mathrm{~mL}$ of sediment was frozen with liquid $\mathrm{N}$ for microbial analyses. Remaining material was stored in plastic bags at $5^{\circ} \mathrm{C}$ pending further processing within $24 \mathrm{~h}$.

The WC\% per sediment layer was calculated after drying sediments at $60{ }^{\circ} \mathrm{C}$ for $72 \mathrm{~h}$. To quantify the percent of organic matter (OM\%), dried sediments were further combusted at $500{ }^{\circ} \mathrm{C}$ for $4 \mathrm{~h}$.

Water-soluble organic matter was extracted from sediments (volume ratio 1:5) using $2 \mathrm{M} \mathrm{KCl}$ (Gabor et al. 2015). The salt solution mimics ionic strength of the stream water and thus avoids extreme osmotic stress on microorganisms' cells upon rewetting when using pure water (McNamara and Leff 2004). Besides, unlike pure water, salty leaching solutions appear preferable if spectrometric dissolved organic matter measures are targetted (Gabor et al. 2015). Extracted samples were centrifuged (3400 rpm, $10 \mathrm{~min}$ ) and filtered through pre-ashed $\left(450{ }^{\circ} \mathrm{C}, 4 \mathrm{~h}\right)$ Whatman GF/ $\mathrm{F}$ filters (Maidstone, England, UK, $0.7 \mu \mathrm{m}$ nominal pore size). We then used a liquid chromatographyorganic carbon-organic nitrogen detection system (LC-OCD-OND, DOC-Labor Huber, Karlsruhe, Germany) (Huber et al. 2011; Graeber et al. 2012) to measure total dissolved organic $\mathrm{C}$ and $\mathrm{N}$ concentrations, and molecular size distributions including UVabsorbance of size fractions. Bulk specific ultraviolet absorbance at $254 \mathrm{~nm}\left(\mathrm{SUVA}_{254} ; \mathrm{L} \mathrm{mg} \mathrm{C}^{-1} \mathrm{~m}^{-1}\right)$, a surrogate of average aromaticity (Weishaar et al. 2003), was calculated by normalizing decadal absorbance at $254 \mathrm{~nm}$ to DOC concentration. Molecular size distributions allowed to define three fractions of WSOC (von Schiller et al. 2015): (i) 'biopolymers', i.e. non-humic high molecular weight substances (HMWS $>10 \mathrm{kDa}$ ) of hydrophilic character and no unsaturated structures like polysaccharides and proteins, (ii) aromatic 'humic or humic-like substances' (HS) including building blocks, and (iii) 'low molecular-weight substances' (LMWS) including acidic and neutral substances. Fractions were assigned based on standards of the International Humic Substances Society. Before analysis, all samples were stored at $5^{\circ} \mathrm{C}$ for less than 2 weeks to avoid changes of dissolved organic matter composition (Heinz and Zak 2018). The same system also provides watersoluble organic nitrogen (WSON) concentrations. For the size fractions with detected N (HMWS and HS) we also computed molar $\mathrm{C}: \mathrm{N}$ ratios. Leaching yields of 
WSOC and WSON were calculated as a fraction of dry mass (mg g DM ${ }^{-1}$ ). Besides sediment leachates, we also used LC-OCD-OND to analyze the surface and drainage water of the microcosms for DOC and DON concentrations.

Microbial community composition

We assessed microbial community composition in functional terms of oxygen requirements (aerobic vs. anaerobic taxa) and $\mathrm{CH}_{4}$ cycling (methanogens vs. methanotrophs) by amplicon sequencing of the $16 \mathrm{~S}$ rRNA gene and using FAPROTAX ("functional annotation of prokaryotic taxa", Louca et al. 2016) to assign microbial functions to taxa data. Total community DNA was extracted from 0.25 -g sediment samples stored at $-80{ }^{\circ} \mathrm{C}$ using the PowerSoil DNA isolation kit (MoBio Laboratories, CA, USA) according to the manufacturer's instructions with exception of a bead beating step performed in a MP FastPrep-24 5G High Speed Homogenizer (MP Biomedical, CA, USA) during $30 \mathrm{~s}$ at a speed of $5 \mathrm{~m} \mathrm{~s}^{-1}$. The concentration and purity of DNA was examined using a NanoDrop spectrophotometer (Fisher Scientific, Schwerte, Germany). The measured concentrations ranged between 20 and $63 \mathrm{ng} \mu \mathrm{L}^{-1}$ and were expressed in ng per $g$ of dry mass (DM). The DNA was amplified with a primer pairs targeting the V4 region of the $16 \mathrm{~S}$ ribosomal RNA (rRNA) gene for archaea and bacteria (515 F and 806R; Walters et al. 2016, conforming with the Earth Microbiome Project, Thompson et al. 2017). The PCR amplification, Illumina MiSeq library preparation (including equimolar pooling of amplicons from different samples) and paired-end sequencing (V3 chemistry) was carried out by LGC Genomics (Berlin, Germany). Sequence reads (clipped from adaptor and primer sequence remains) were processed using the DADA2 package in $\mathrm{R}$ (version 1.2.0) (Callahan et al. 2016). Forward and reverse reads were filtered $(\max N=0$, $\operatorname{maxEE}=2$, truncQ $=2$ ) and truncated to $180 \mathrm{bp}$, corresponding to a minimum quality score of 30 along the reads. An average of $94 \%$ of the reads were retained after quality filtering. Chimeric sequences ( $<5 \%$ of unique sequences) were removed using the removeBimeraDenovo function. The resulting amplicon sequence variants (ASVs, analogous to operational taxonomic units) were used to construct a table containing relative abundances of ASVs across all samples. ASVs were taxonomically classified with BlastN using a lowest common ancestor (LCA) approach on a manually curated version (silvamod, Lanzén et al. 2012) of the Silva SSURef database (version 128, Pruesse et al. 2007) in MEGAN5 (Huson et al. 2007) with the following LCA parameters: top percent 2 , minimum bit score 155 , minimum number of hits 1. Illumina MiSeq $16 \mathrm{~S}$ rRNA amplicon sequence data was submitted to the NCBI Short Read Archive (accession number SRP137655). Functional trait estimation of the taxa was performed using FAPROTAX (Louca et al. 2016) on the ASVs. Using the current literature on cultured strains, FAPROTAX maps microbial taxa to established metabolic or other ecologically relevant functional traits. The ASV Table (9404 ASVs in total, average ASV richness per sample $1401 \pm 535$, SE), including taxonomic classification of ASVs, was normalized to the total sum of reads (TSS normalization) in each sample before functional trait estimation. From this functional table, we selected the relative abundance of methanotrophs and methanogens to examine their variation. We also selected main aerobic and anaerobic functions to sum their relative abundances. The aerobic processes included methanotrophy, aerobic ammonia oxidation, aerobic nitrite oxidation, nitrification and aerobic chemoheterotrophy. The anaerobic processes encompassed methanogenesis, respiration of sulfur compounds, denitrification, fermentation, iron respiration and chlorate reducers.

\section{Comparative field sampling}

In August 2015, after approximately 6 weeks of desiccation period, we conducted a comparative field sampling for gaseous $\mathrm{C}$ fluxes and chemical characteristics of sediments. The aim of this sampling was to obtain results under in situ desiccation conditions that could be used to complement the outcomes concerning $\mathrm{C}$ fluxes using the microcosm set up and to discuss the potential variables that can shape experimental findings under field conditions. Gaseous $\mathrm{C}$ fluxes were measured using 1.2-L soil chambers $(\mathrm{n}=3)$ provided with a septum-cap and a collar that was inserted $5 \mathrm{~cm}$ into the sediments. After $1 \mathrm{~h}$ of collar insertion, chambers were capped and four gas tight gas vials (10 $\mathrm{mL}$ ) were collected from headspace over $1 \mathrm{~h}$ by using 20-mL syringes and pre-evacuated gas vials (Machery-Nagel GmbH \& Co., Berlin, Germany). Surface 
and deep sediments were collected with a hand shovel and transported in plastic bags to the laboratory to determine $\mathrm{WC} \%, \mathrm{OM} \%$, and the quantity and quality of water-soluble organic matter within $24 \mathrm{~h}$ after collection. The $\mathrm{CO}_{2}$ and $\mathrm{CH}_{4}$ fluxes were determined on the same day of sampling as described for microcosms experiments.

\section{Statistical analysis}

Changes of chemical and microbial variables through desiccation time and per sediment layer were examined by means of general linear models (GLM). A factoral design including desiccation time $(0,3,6$ and 9 weeks) and sediment layer (surface and deep) as fixed factors as well as their interaction (time $\mathrm{x}$ sediment) were included in the models. The temporal factor desiccation time could be treated as fixed because measurements were done in different microcosms (Fig. 1), Holm's post hoc test were used for planned comparisons between pre-desiccation wet conditions (i.e., 0 weeks) and the 3 desiccation dates (3, 6 and 9 weeks). The effects of rainfall and duration of precedent desiccation on cumulative gas fluxes were examined using a similar GLM that included the factors rainfall size (dry or $0 \mathrm{~mm}, 4$ and $21 \mathrm{~mm}$ ) and desiccation time (3, 6 and 9 weeks) as well as their interaction (time $\mathrm{x}$ rainfall). Holm's post hoc tests were used for comparisons among rainfall sizes by each desiccation period. When significant differences were found for cumulative fluxes, we graphically examined the gaseous flux trajectories over the monitoring time $(-2,0,2,6$ and $24 \mathrm{~h})$ in response to the different rainfall treatments $(0,4$ and $21 \mathrm{~mm})$.

Statistical analyses were performed using SPSS software vs. 24 (Chicago, IL, USA). Results were considered significant at $\mathrm{P}<0.05$.

\section{Results}

Sediment water content and dissolved oxygen

Sediment water content (WC\%) of the whole microcosms decreased from $42 \%$ on average at the beginning to $9 \%$ after 9 weeks of desiccation (i.e. 62 days) (Fig. 2a). In parallel, DO increased faster in surface than in deep sediments and approached saturation at approx. $9 \mathrm{mg} \mathrm{L}^{-1}$ after 10 days of desiccation
(Fig. 2a). After 24 days, DO in both sediment layers matched and remained so until the end of the experiment (Fig. 2a). WC\% measured in surface and deep sediments in dry microcosms (i.e., $0 \mathrm{~mm}$ ) decreased significantly after 6 and 9 weeks if compared with initial conditions (Holm's post hoc test, $\mathrm{P}<0.05$ ) (Fig. 2b, c). Simulated rainfall after each desiccation time increased $\mathrm{WC} \%$ in both sediment layers with the treatment of $21 \mathrm{~mm}$ generally inducing the largest values (Fig. 2b, c).

\section{Gaseous C fluxes}

Over the 9 weeks of desiccation, we found significant temporal variation in the fluxes of $\mathrm{CO}_{2}$ and $\mathrm{CH}_{4}$ (Fig. 3). The $\mathrm{CO}_{2}$ fluxes reflected a change in the direction of the emission with increasing fluxes at the beginning of desiccation followed by a gradually decreasing pattern. Average $\mathrm{CO}_{2}$ fluxes increased from $5.3 \mathrm{mg} \mathrm{C} \mathrm{m}^{-2} \mathrm{~h}^{-1}(\mathrm{t}=-3$ days $)$ to $38 \mathrm{mg} \mathrm{C}$ $\mathrm{m}^{-2} \mathrm{~h}^{-1}$ after drainage $(\mathrm{t}=0$ days) and peaked with an average of $383 \mathrm{mg} \mathrm{C} \mathrm{m}^{-2} \mathrm{~h}^{-1}$ after 11 days of desiccation (Fig. 3). Afterwards, $\mathrm{CO}_{2}$ fluxes gradually decreased with a minimum average value of $1.2 \mathrm{mg} \mathrm{C}$ $\mathrm{m}^{-2} \mathrm{~h}^{-1}$ at the end of the experiment. $\mathrm{CH}_{4}$ fluxes were higher than $\mathrm{CO}_{2}$ fluxes in the beginning of the experiment, and the fluctuations of $\mathrm{CH}_{4}$ fluxes through desiccation were more dynamic than those of $\mathrm{CO}_{2}$ fluxes (Fig. 3). Average $\mathrm{CH}_{4}$ fluxes increased from $-5 \mathrm{mg} \mathrm{C} \mathrm{m}^{-2} \mathrm{~h}^{-1}$ ( $\mathrm{t}=-3$ days) to $28 \mathrm{mg} \mathrm{C} \mathrm{m}^{-2} \mathrm{~h}^{-1}$ after drainage $(\mathrm{t}=0$ days $)$, with the highest fluxes after 3 days of desiccation $\left(30 \mathrm{mg} \mathrm{C} \mathrm{m}^{-2} \mathrm{~h}^{-1}\right.$ ). At $\mathrm{t}=6$ days, fluxes exhibited a sharp drop to $-10 \mathrm{mg} \mathrm{C}$ $\mathrm{m}^{-2} \mathrm{~h}^{-1}$, remained low with an average value of $0.03 \mathrm{mg} \mathrm{C} \mathrm{m}^{-2} \mathrm{~h}^{-1}$ after 27 days of desiccation, and were not detectable afterwards (Fig. 3).

During the simulated rainfall events following desiccation periods of variable duration, we detected fluxes only for $\mathrm{CO}_{2}$ but not for $\mathrm{CH}_{4}$. Overall, the cumulative $\mathrm{CO}_{2}$ fluxes $24 \mathrm{~h}$ after rainfall decreased with longer preceding desiccation. However, the response to the different rainfall sizes varied depending on the desiccation time; differences appearing only after 3 and 9 weeks (interaction term time $x$ rainfall: $\mathrm{P}<0.05$, Holm's post hoc test, $\mathrm{P}<0.05$ ) (Fig. 4a). Furthermore, the trajectories of $\mathrm{CO}_{2}$ fluxes examined over $24 \mathrm{~h}$ varied differently in response to the applied rainfall pulses, yet such responses were not equal after 3 and 9 weeks (Fig. 4b,c). After 3 weeks, while the 


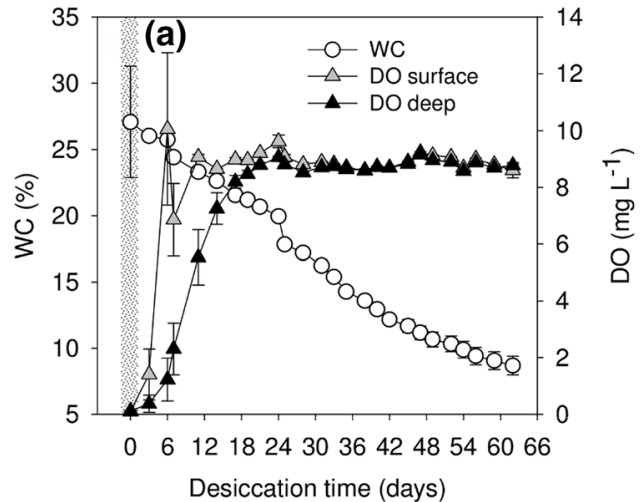

Fig. 2 a Variation of water content (WC\%) in the whole microcosms and dissolved oxygen (DO) percentage in surface and deep sediments of microcosms that kept dry over the entire desiccation period (mean $\pm \mathrm{SE}, \mathrm{n}=9)$. Mean $\mathrm{WC} \%( \pm \mathrm{SE}$, $\mathrm{n}=3$ ) calculated in surface (b) and deep (c) sediments over desiccation time and after the different rainfall sizes (0, 4 and 21 $\mathrm{mm})$. Asterisks $(*)$ denote significant $(\mathrm{P}<0.05)$ differences of

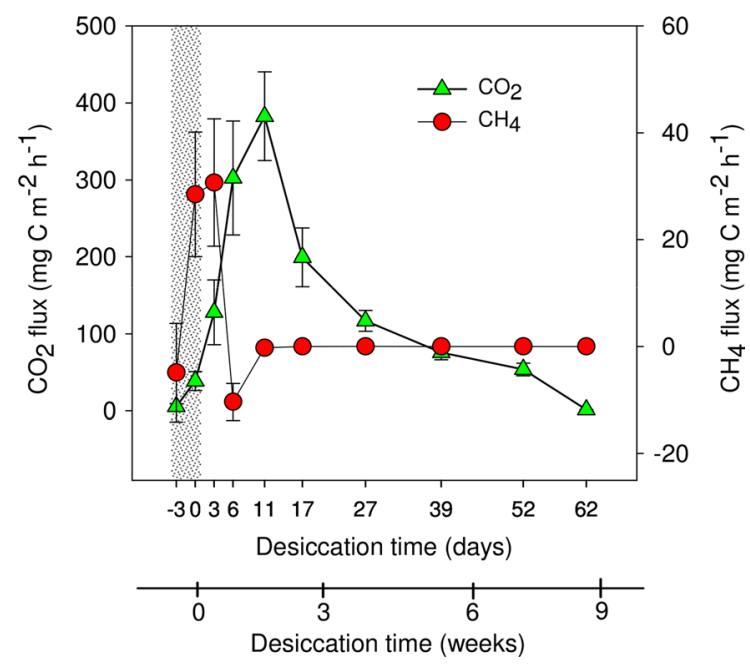

Fig. 3 Variation of mean $\left( \pm \mathrm{SE}, \mathrm{n}=9\right.$ ) fluxes of $\mathrm{CO}_{2}$ and $\mathrm{CH}_{4}$ from sediments before microcosms drainage (microcosms with a overlaying water column) $(\mathrm{t}=-3$ days), immediately after drainage $(\mathrm{t}=0$ days $)$ and several times after drainage and desiccation. The dashed bar illustrates the wet conditions of the pre-desiccation

$\mathrm{CO}_{2}$ fluxes in the dry microcosms (i.e. $0 \mathrm{~mm}$ ) hardly changed over $24 \mathrm{~h}$, the $4-\mathrm{mm}$ and $21-\mathrm{mm}$ rainfall treatments induced considerable dynamics, yet with contrasting patterns (Fig. 4b). For example, an instantaneous $(t=0)$ peak in the average flux of $157 \mathrm{mg} \mathrm{C}$ $\mathrm{m}^{-2} \mathrm{~h}^{-1}$ was found after $4 \mathrm{~mm}$ rainfall when compared with the flux before $\left(20 \mathrm{mg} \mathrm{C} \mathrm{m}^{-2} \mathrm{~h}^{-1}\right.$ at $\mathrm{t}=-3$ ) (Fig. 4b). Conversely, the $21-\mathrm{mm}$ rainfall first dry treatments (i.e., dry $+0 \mathrm{~mm})$ after each desiccation period with pre-desiccation conditions ( 0 weeks) after Holm's post hoc test for multiple comparisons. The dashed bar illustrates the wet conditions of the pre-desiccation. The continuous line connects values of $\mathrm{WC} \%$ in microcosms that received no rainfall (dry or 0 $\mathrm{mm}$ ) for a better comparison

caused an instantaneous drop in $\mathrm{CO}_{2}$ flux (19 mg C $\mathrm{m}^{-2} \mathrm{~h}^{-1}$ ) to levels below those in dry conditions (i.e., $0 \mathrm{~mm}$ : $81 \mathrm{mg} \mathrm{C} \mathrm{m}^{-2} \mathrm{~h}^{-1}$ ), but then followed with a peak value of $274 \mathrm{mg} \mathrm{C} \mathrm{m}^{-2} \mathrm{~h}^{-1}$ after $2 \mathrm{~h}$. After $24 \mathrm{~h}$, $\mathrm{CO}_{2}$ fluxes slightly increased under the 4-mm rainfall, while a drop was detected under the 21-mm rainfall (Fig. 4b). After 9 weeks of desiccation, rainfall also induced dynamics of $\mathrm{CO}_{2}$ fluxes; yet, patterns were more similar between the two rainfall sizes and fluxes in the dry microcosms (i.e. $0 \mathrm{~mm}$ ) were generally lower (Fig. 4c).

Organic $\mathrm{C}$ and $\mathrm{N}$ in surface water and sediments

By considering the water volume moving through microcosms, the mean amount $( \pm$ SD) of DOC and DON of surface water in the microcosms at the start of the experiment were $0.5 \pm 0.02 \mathrm{mg} \quad \mathrm{C}$ and $0.03 \pm 0.01 \mathrm{mg} \mathrm{N} \mathrm{L}^{-1}$, respectively. Amounts were higher in the drained water, especially for DOC, with an average of $1 \pm 0.2 \mathrm{mg} \mathrm{C}$ while the amount of DON was $0.04 \pm 0.01 \mathrm{mg} \mathrm{N}$. The average initial sediment $\mathrm{OM} \%$ was $8.0 \% \pm 2.4$ and $11.6 \% \pm 3.5$ in surface and deep sediments, respectively. The average OM\% did not show significant variation as desiccation progressed as well as between sediment layers (data not shown).

In surface and deep sediments, concentrations of WSOC after 3 and 9 weeks significantly differed from initial conditions (Holm's post hoc test, $\mathrm{P}<0.05$, 
Fig. 4 a Variation of mean $( \pm \mathrm{SE}, \mathrm{n}=3$ ) cumulative fluxes of $\mathrm{CO}_{2}$ following $24 \mathrm{~h}$ in response to desiccation (dry $+0 \mathrm{~mm}$ ) and to variable rainfall size $($ dry +4 and dry $+21 \mathrm{~mm})$ after the different desiccation weeks. Different letters denote significant differences between rainfall treatments after Holm's post hoc test for multiple comparisons. Variation of mean $( \pm \mathrm{SE}, \mathrm{n}=3$ ) fluxes of $\mathrm{CO}_{2}$ before $(\mathrm{t}=-2 \mathrm{~h})$, immediately $(\mathrm{t}=0 \mathrm{~h})$ and following rainfall events ( $\mathrm{t}=2,6$ and $24 \mathrm{~h}$ ) after 3 (b) and 9 (c) weeks of desiccation
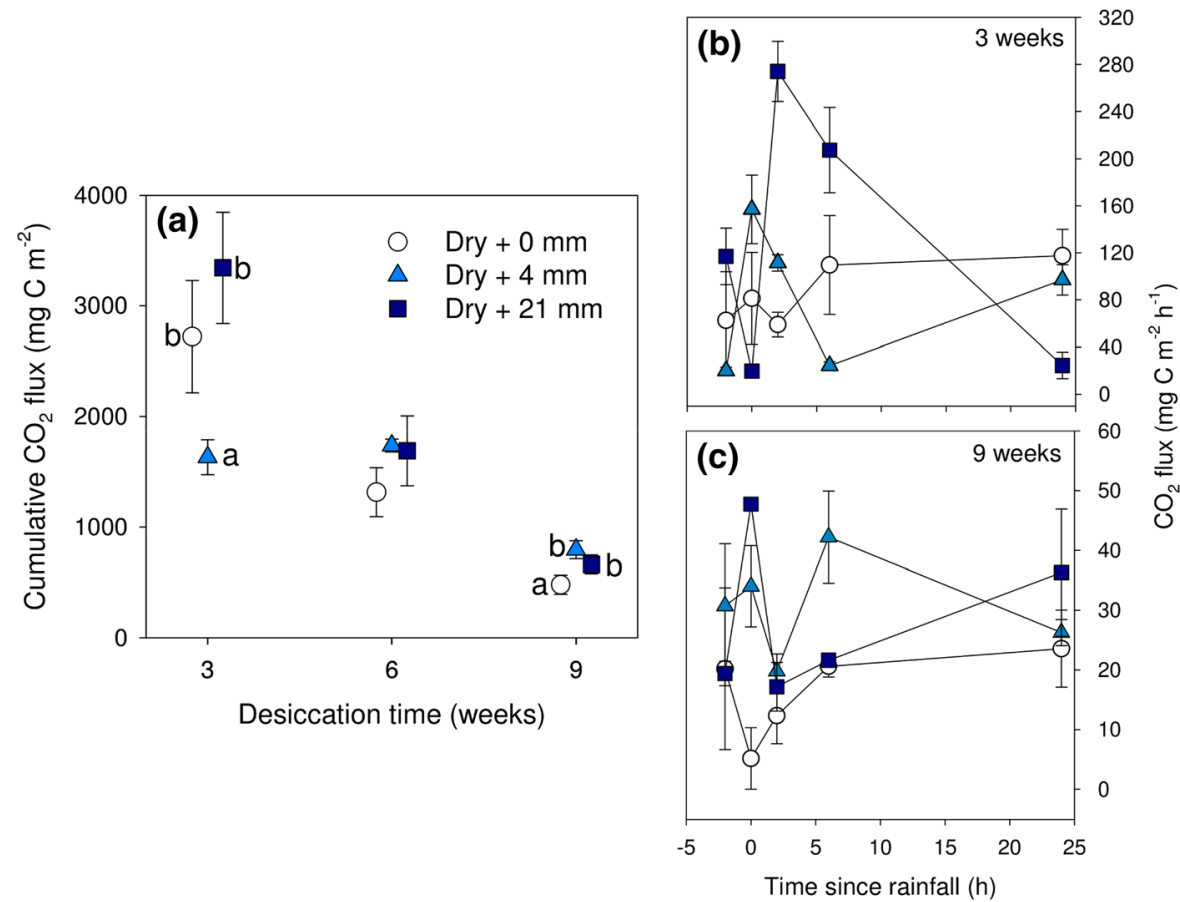

Fig. 5a). For example, average WSOC in the microcosms dropped more than half during the first 3 weeks, from 0.93 to $0.36 \mathrm{mg} \mathrm{C} \mathrm{g}^{-1} \mathrm{DM}$ in surface and from 0.86 to $0.33 \mathrm{mg} \mathrm{C} \mathrm{g}^{-1} \mathrm{DM}$ in deep layers, respectively (Fig. 5a). In the case of WSON, significant differences with respect to initial conditions were found for all desiccation periods (Holm's post hoc test, $\mathrm{P}<0.05$, Fig. 5b). No significant differences between sediment layers were detected for both variables. In parallel, $\mathrm{SUVA}_{254}$, tended to increase over desiccation time in both surface and deep sediments (Fig. 5c), yet we only found significant differences after 3 and 9 weeks when compared with initial conditions (Holm's post hoc test, $\mathrm{P}<0.05$, Fig. $5 \mathrm{c}$ ). Again, no differences between sediment layers were detected.

Before desiccation, the largest fraction of WSOC in surface and deep sediments was, respectively, in form of HS (54 and 52\%) followed by LMWS (37 and 36\%) and HMWS (9.4 and 12\%). These relative differences were maintained during the whole experiment (Fig. 6a, b). There were no significant differences between the two sediment layers for any fraction. The only changes over desiccation were detected for \%HMWS in both sediment layers, which dropped significantly after 3 and 6 weeks when compared with pre-desiccation conditions (Holm's post hoc test,
$\mathrm{P}<0.05)$, although an increasing trend after 9 weeks of desiccation appeared (Fig. 6a, b).

The two analyzed high-molecular fractions for WSON, HS and HMWS, varied similarly in both sediment layers showing significant differences after desiccation (Holm's post hoc test, $\mathrm{P}<0.05$ ) (Fig. 6c, d). During the whole experiment, HS was the dominant fraction of WSON. During initial conditions $\% \mathrm{HS}$ and \% HMWS were, respectively, 60 and $40 \%$ in surface (Fig. 6c) and 43 and $57 \%$ in deep sediments (Fig. 6d). Because of the contrasting temporal patterns, these relative differences amplified as desiccation progressed. Thus, after 9 weeks of desiccation, $\%$ HMWS and \%HS were, respectively, 22 and $78 \%$ in surface (Fig. 6c) and 20 and $80 \%$ in deep sediments (Fig. 6d).

Before desiccation, C:N molar ratios were about 4-times higher for HS than for HMWS in surface (mean $\pm \mathrm{SD}, 18 \pm 2$ and $4.3 \pm 0.4$, respectively) and deep (16 \pm 1 and $5 \pm 1.5$, respectively) layers (Fig. 6e, f). Overall, in both sediment layers, ratios for HMWS increased as desiccation progressed, showing significant differences after 9 weeks (Holm's post hoc test, $\mathrm{P}<0.05)$. Such increase led HMWS to have similar $\mathrm{C}: \mathrm{N}$ to $\mathrm{HS}$ at the end of the experiment (Fig. 6e, f). 


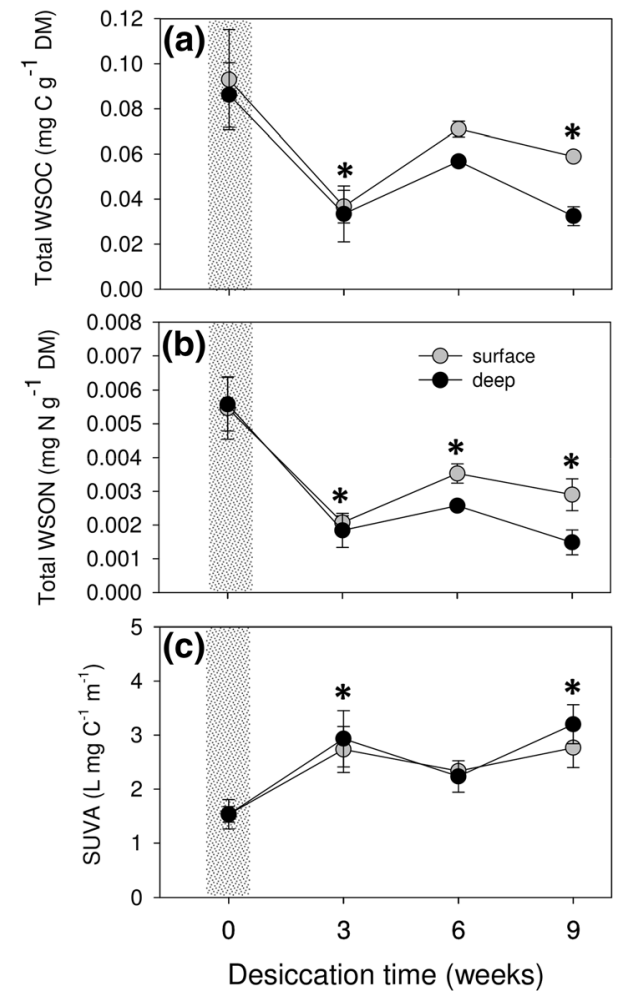

Fig. 5 Variation of mean $( \pm \mathrm{SE}, \mathrm{n}=3)$ concentrations of water-soluble organic carbon (WSOC) (a), water-soluble organic nitrogen (WSON) (b), and specific UV absorbance $\left(\mathrm{SUVA}_{254}\right)(\mathbf{c})$ in surface and deep sediment leachates over desiccation time. Asterisks $(*)$ denote significant $(\mathrm{P}<0.05)$ differences to pre-desiccation conditions ( 0 weeks) for both sediment layers after Holm's post hoc test for multiple comparisons. The dashed bar illustrates the wet conditions of the pre-desiccation

Microbial community functions

During the whole experiment, the relative abundance of summed aerobic functional groups was larger than that from anaerobic groups both in surface and deep sediment (Fig. 7a). Indeed, we found no significantly different abundances of these functional groups between sediment layers. When compared with initial conditions ( 0 weeks) only a significant reduction was found for anaerobic functions in both sediment layers (Holm's post hoc test, $\mathrm{P}<0.05$, Fig. 7a).

When we focused on $\mathrm{CH}_{4}$-related functional groups, i.e., aerobic methanotrophs and anaerobic methanogens (Fig. 7b, c), we found that their average relative abundance varied within the same range of magnitude over the experiment. The relative abundance of methanogens was stable over the experiment.
Only the abundance of methanotrophs in deep sediments seemed to show a marked increase after 3 weeks of desiccation when compared with pre-desiccation conditions (0 weeks). It was at this time when the largest variation between sediment layers was also observed, yet these results were not statistically significant (interaction term time $x$ sediment layer $P=0.057$ ) (Fig. 7b).

\section{Discussion}

This study underpins that the duration of desiccation, a proxy of drying severity, is an important driver of biogeochemical processing in intermittent streams. As predicted, drying modulated microbial functions and the evasion of $\mathrm{CO}_{2}$ and $\mathrm{CH}_{4}$ from streambed sediments to the atmosphere, both during progressing desiccation as well as in later rainfall-induced evasion peaks. Moreover, desiccation altered the quantity and quality of water-soluble organic matter, with implications for biogenic gas production and downstream organic matter transport upon rewetting.

Gaseous C fluxes in response to desiccation

In agreement with other studies (von Schiller et al. 2014; Gómez-Gener et al. 2015; 2016; Obrador et al. 2018), we found that $\mathrm{CO}_{2}$ fluxes to the atmosphere boosted in response to desiccation both in laboratory and field conditions. The $\mathrm{CO}_{2}$ flux we observed in situ after 6 weeks of non-flow conditions $(234 \pm 21 \mathrm{mg} \mathrm{C}$ $\mathrm{m}^{-2} \mathrm{~h}^{-1}$, Table 1) tended to be higher but overlapped with estimates reported from a field survey at global scale for other temperate streams under dry conditions $\left(89 \pm 154 \mathrm{mg} \mathrm{C} \mathrm{m}^{-2} \mathrm{~h}^{-1}\right.$, median $\left.=50\right)$ (Keller et al. 2020). This finding supports the importance of considering drying aquatic ecosystems in global upscaling and modeling studies on C cycle (Marcé et al. 2019).

Contrary to $\mathrm{CO}_{2}, \mathrm{CH}_{4}$ fluxes were low $\left(5.5 \pm 9.6 \mathrm{mg} \mathrm{C} \mathrm{m}^{-2} \mathrm{~h}^{-1}\right)$ in our microcosms and not detectable in situ, which agrees with previous work reporting low $\mathrm{CH}_{4}$ emissions in exposed sediments of inland waters, typically falling below $0.5 \mathrm{mg} \mathrm{C}$ $\mathrm{m}^{-2} \mathrm{~h}^{-1}$ (Marcé et al. 2019).

As predicted, temporal progression of desiccation impacted $\mathrm{CO}_{2}$ and $\mathrm{CH}_{4}$ fluxes to atmosphere. Fluxes of both gases peaked during early desiccation and then decreased. This pattern was especially quick for $\mathrm{CH}_{4}$. 

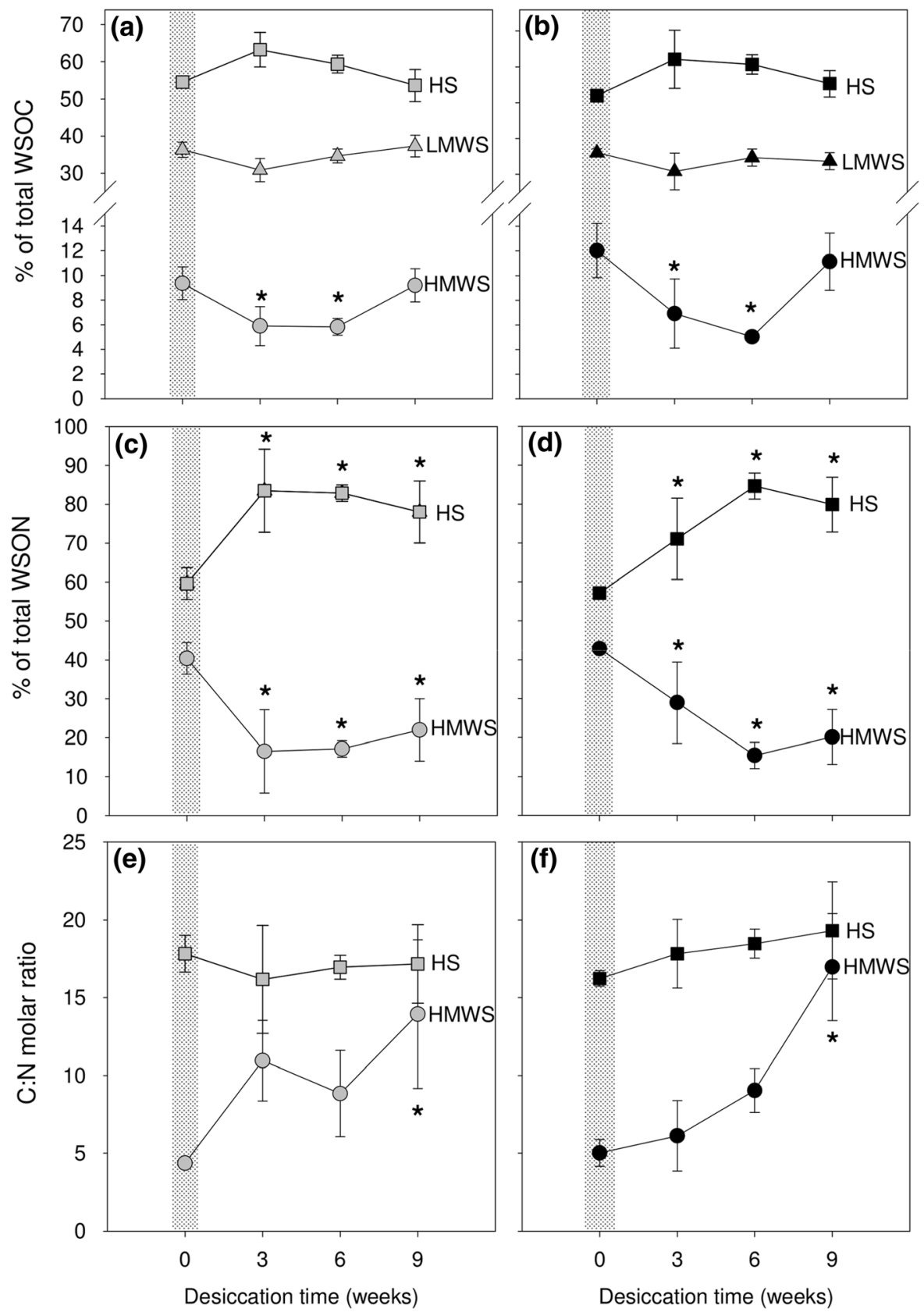

Fig. 6 Variation of the percentage contribution of the different fractions to the total water-soluble organic carbon (WSOC) and (0 weeks) after Holm's post hoc test for multiple comparisons. The dashed bar illustrates the wet conditions of the predesiccation. HMWS $=$ high molecular weight substances, LMWS = low molecular weight substances and HS = humic surface $(\mathbf{a}, \mathbf{c}, \mathbf{e})$ and deep (b, d, f) sediment leachates, respectively, over desiccation time. Asterisks (*) denote significant $(\mathrm{P}<0.05)$ differences to pre-desiccation conditions

or humic-like substances. Values are means $\pm \mathrm{SE}(\mathrm{n}=3)$

Gaseous fluxes are influenced by multiple factors, including physical forcing and microbial production (Looman et al. 2017). Due to low gas diffusion, water acts as a physical barrier curbing gas evasion from wet sediments, its absence in dry streambeds in turn enhances gaseous C emissions (Gallo et al. 2014; 

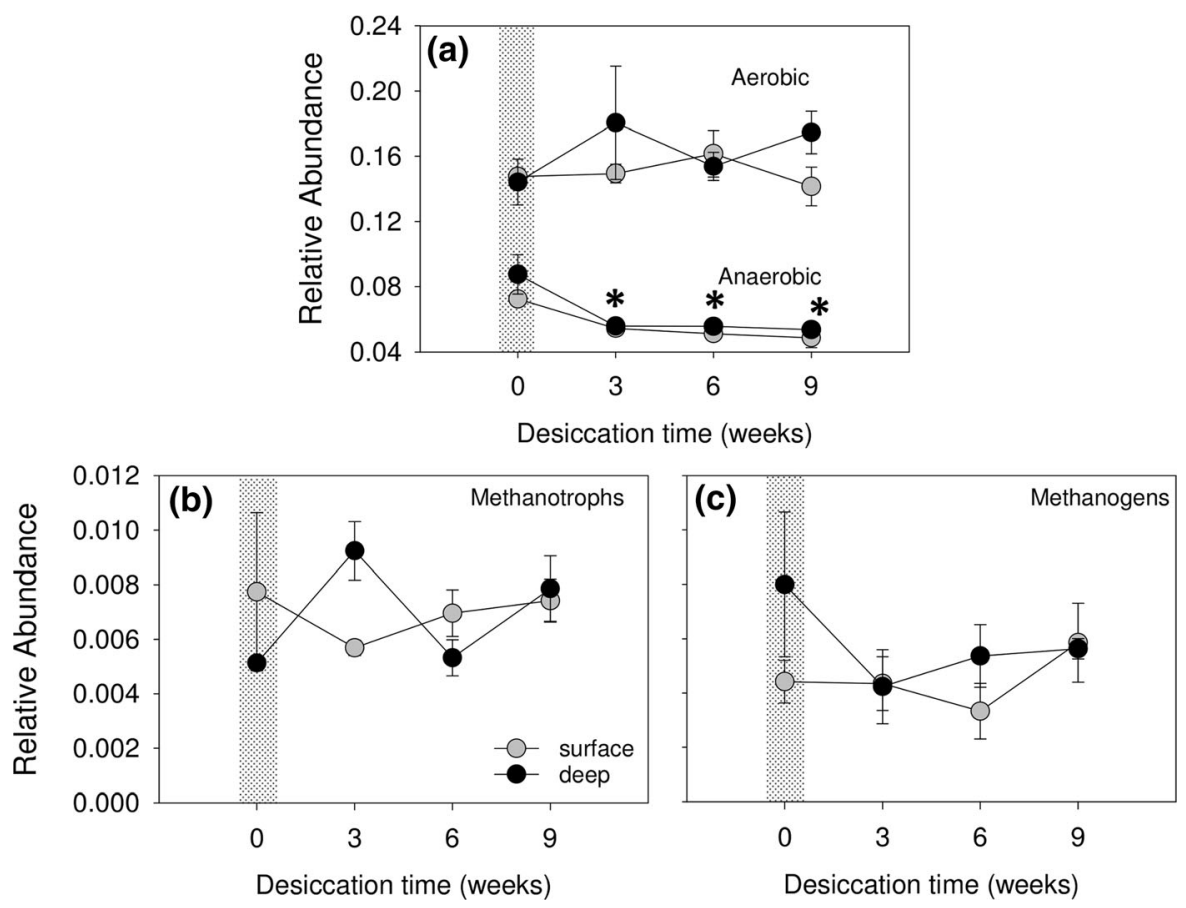

Fig. 7 Variation in relative abundances (\%) of $16 \mathrm{~S}$ rRNA sequence tags from aerobic and anaerobic functional groups (a), methanotrophs (b) and methanogens (c) identified by using FAPROTAX in surface and deep layers over desiccation time. Asterisks $(*)$ denote significant $(\mathrm{P}<0.05)$ differences to pre-

Gómez-Gener et al. 2015; 2016). This physical mechanism may explain the rapid peak of $\mathrm{CH}_{4}$ observed 3 days after drying of microcosms. Later, we observed low $\mathrm{CH}_{4}$ fluxes from sediments exposed to air, likely due to lower production in increasingly oxic sediment and oxidation of $\mathrm{CH}_{4}$ prior to evasion to atmosphere (Koschorreck 2000; Wang et al. 2006; Jin et al. 2016; Kosten et al. 2018). Unlike $\mathrm{CH}_{4}, \mathrm{CO}_{2}$ emissions progressively increased during the first 11 days of desiccation. Besides improved physical gas exchange, oxygenation of exposed sediments favors aerobic transformation processes (Gómez-Gener et al. 2015; von Schiller et al. 2017), microbial growth and associated biogenic $\mathrm{CO}_{2}$ production (Fromin et al. 2010). Biogenic $\mathrm{CO}_{2}$ and $\mathrm{CH}_{4}$ dynamics are prone to show opposite behavior due to different redox requirements of involved microorganisms (Marcé et al. 2019). Accordingly, we hypothesized contrasting patterns in the relative abundance of putatively anaerobic vs. aerobic microbial functional traits in sediments as desiccation progressed. Over 9-weeks of drying, relative abundance of aerobic microbial traits desiccation conditions ( 0 weeks) after Holm's post hoc test for multiple comparisons for both sediment layers. The dashed bar illustrates the wet conditions of the pre-desiccation. Values are means $\pm \mathrm{SE}(\mathrm{n}=3)$

did not vary, but anaerobic functional traits decreased. The slight decrease in the relative abundance of methanogens in deep sediments after 3 weeks of desiccation is consistent with the low $\mathrm{CH}_{4}$ emissions found over desiccation. Besides, this drop corresponded with the significant increase of methanotrophs, which suggests oxygenation reached deep sediments. In fact, we detected negative $\mathrm{CH}_{4}$ fluxes in some microcosms within the first $27 \mathrm{~d}$ of desiccation, which indicates that methanotrophy could be active in this timeframe.

These results illustrate a microbial functional response to drying, yet should be interpreted with caution as they are based on functional trait estimation, rather than direct detection of functional gene expression. In addition, relative abundance data does not capture microbial responses that lead to an overall biomass increase, rather than changes in the relative proportions of organisms.

The decrease of $\mathrm{CO}_{2}$ emission as sediment became drier was also observable in cumulative fluxes during $24 \mathrm{~h}$. These findings indicate that after $17 \mathrm{~d}$ of 
Table 1 Mean (SE) values, $\mathrm{n}=3$, of variables studied after 6 weeks of desiccation in the study stream under in situ conditions

\begin{tabular}{|c|c|c|}
\hline \multirow[t]{2}{*}{ Variable (units) } & \multicolumn{2}{|c|}{ Sediment layer } \\
\hline & Surface & Deep \\
\hline $\mathrm{WC}(\%)$ & $56(4)$ & $42(5)$ \\
\hline $\mathrm{OM}(\%)$ & $29(6)$ & $12(2)$ \\
\hline WSOC (mg C g $\left.{ }^{-1} \mathrm{DM}\right)$ & $0.18(0.05)$ & $0.05(0.01)$ \\
\hline HMWS $(\%)$ & $9.4(0.6)$ & $12(1)$ \\
\hline LMWS (\%) & $59(2)$ & $53(2)$ \\
\hline $\mathrm{HS}(\%)$ & $31(1)$ & $34(2)$ \\
\hline WSON (mg N g $\left.{ }^{-1} \mathrm{DM}\right)$ & $0.014(0.01)$ & $0.004(0.001)$ \\
\hline HMWS $(\%)$ & $30(12)$ & $28(5)$ \\
\hline HS (\%) & $70(12)$ & $71(5)$ \\
\hline Molar C:N ratio HMWS & $9.4(2.5)$ & $13.7(0.7)$ \\
\hline Molar C:N ratio HS & $10(3.4)$ & $15(4)$ \\
\hline $\operatorname{SUVA}_{254}\left(\mathrm{~L} \mathrm{mg} \mathrm{C} \mathrm{m}^{-1} \mathrm{~m}^{-1}\right)$ & $2.3(0.1)$ & $2.4(0.3)$ \\
\hline Flux of $\mathrm{CO}_{2}\left(\mathrm{mg} \mathrm{C} \mathrm{m}^{-2} \mathrm{~h}^{-1}\right)$ & \multicolumn{2}{|c|}{$234.52(21)$} \\
\hline Flux of $\mathrm{CH}_{4}\left(\mathrm{mg} \mathrm{C} \mathrm{m}^{-2} \mathrm{~h}^{-1}\right)$ & \multicolumn{2}{|c|}{ nd } \\
\hline
\end{tabular}

$W C$ water content, $O M$ organic matter, WSOC water soluble organic carbon, WSON water soluble organic nitrogen, HMWS high molecular weight substances, LMWS low molecular weight substances, HS humic substances. $S U V A_{254}$ spectroscopic index indicative of aromaticity of organic matter, $n d$ no detected

desiccation, sediment water becomes a limiting factor for microbial activity, probably through the direct impact on the survival of microbial communities (Amalfitano et al. 2008) and by limiting resource supply in a dry matrix (Schimel 2018). This plausible loss of activity did not translate into substantial changes in the relative abundance of aerobic microbial groups, which remained constant during the experiment. Finding synchronisms between microbial community and activity patterns is not easy (Prosser 2012). We must note that we are examining relative abundances of microbial traits (instead of absolute ones), and DNA-based community analysis may in addition suffer from the persistence of DNA material from dead and therefore inactive members of the community. Furthermore, the persistence of extracellular enzymatic activity during severe desiccation (Zoppini and Marxsen 2011; Pohlon et al. 2018) has been proposed to contribute to $\mathrm{CO}_{2}$ emissions in dry riverbed sediments at certain levels (Gómez-Gener et al. 2016).
We acknowledge that methods targeting microbial gene expression, such as metatranscriptomics, would have revealed possibly more substantial functional shifts in the microbial community as RNA can be less persistent in the environment than DNA and proteins (Lanzén et al. 2011). In addition, the functional trait estimation used here cannot detect and resolve the effect of facultative anaerobes, which may perform anaerobic processes during anoxia and aerobic processes during oxic conditions.

\section{Gaseous $\mathrm{C}$ fluxes in response to rainfall}

It is well known that transitions from dry to wet conditions can give rise to hot moments with accelerated C and nutrient cycling (McClain et al. 2003; Pinto et al. 2020). In our experiment, sudden water availability by punctuated rainfall had a rapid positive effect on $\mathrm{CO}_{2}$ fluxes to the atmosphere. The recently formulated Ecosystem Control Points concept (Bernhardt et al. 2017) suggests places and moments of disproportionate biogeochemical relevance. Early studies have demonstrated that rewetting events represent such Ecosystem Control Points for respiration and $\mathrm{CO}_{2}$ emissions from intermittent streams (von Schiller et al. 2019), equivalent to the "Birch effect" described in soils. However, as observed in our experiment, anaerobic pathways producing $\mathrm{CH}_{4}$ emissions may not recover rapidly upon rewetting after a severe desiccation (Conrad et al. 2014). Enhanced $\mathrm{CO}_{2}$ fluxes upon water pulse support the importance of WSOC stocks, as a proxy of sediment organic matter, to fuel respiration processes once sediment humidity is no longer limiting microbial activity in water-stressed ecosystems (Sponseller 2007). Yet, as expected, our results demonstrate that the duration of the precedent desiccation period has implications for rewettinginduced $\mathrm{CO}_{2}$ fluxes, as previously observed in soils (Fierer and Schimel 2002) or temporary ponds (Fromin et al. 2010). The magnitude of the response to rewetting decreased with the duration of the preceding desiccation period, highlighting a legacy impact of water stress on microbial communities (Schimel et al. 2017; Schimel 2018).

Water pulses do not always drive positive net $\mathrm{CO}_{2}$ fluxes, and when they occur, biogenic but also physical sources can be involved. For instance, Gallo et al. (2014) found large fluxes of $\mathrm{CO}_{2}$ in response to substantial increases in sediment water content $(\sim$ to 
$50 \%$ ) by rainfalls in extremely dry ( $\sim 0 \%$ sediment moisture) ephemeral streams of Arizona, USA. They proposed that the increased $\mathrm{CO}_{2}$ fluxes immediately after rainfall $(\mathrm{t}=0 \mathrm{~h})$, between 6 and 30 times larger than pre-rainfall, could result from a rapid increase in microbial activity, but especially from a physical displacement immediately after rainfall impact. On the contrary, $\mathrm{CO}_{2}$ may also dissolve in additional interstitial sediment water after rainfall and thus experience dilution in the gas space, which could buffer transitory $\mathrm{CO}_{2}$ exchange to the atmosphere (Looman et al. 2017; Arce et al. 2018). Thus, rewetting effects may likely result from a combination of mechanisms representing sinks and sources, whose relative importance ultimately translate into higher or lower $\mathrm{CO}_{2}$ net fluxes to the atmosphere. After 3 weeks of desiccation, the reduced flux found in our experiment upon the 21-mm rainfall could be attributed to $\mathrm{CO}_{2}$ dissolution into interstitial sediment water. On the contrary, $2 \mathrm{~h}$ after, the substantial flux detected could be indicative of active microbial contribution, including the production of extracellular enzymes (Zoppini and Marxsen 2011; Pohlon et al. 2018). Indeed, narrow peaks of $\mathrm{CO}_{2}$ upon rewetting have been attributed to resuscitation strategies of some microbial groups that become activated within hours of water arrival (Placella et al. 2012). As initially expected, after 9 weeks, when desiccation was more severe, rainfalls of 4 and $21 \mathrm{~mm}$ appeared insufficient to enhance biogenic gaseous $\mathrm{C}$ emissions. In fact, the unique substantial pulse seen after the 21-mm rainfall immediately after water addition was presumably the consequence of dislocation of accumulated gas from already dry and increasingly less active sediments (Gallo et al. 2014) rather than a rapid microbial activation.

Implications of desiccation for leaching of sediment organic matter

Understanding how desiccation affects the dynamics of organic matter is critical in streams with organic matter-rich sediments since excess, unprocessed $\mathrm{C}$ can affect downstream perennial reaches, reservoirs and coastal areas (Datry et al. 2016). The study stream exhibited high DOC concentration in surface water and exfiltrates of incubated sediments before desiccation, indicative of the high organic matter content of the ecosystem. Alongside the gaseous $\mathrm{C}$ fluxes, desiccation also drove changes in the quantity and quality of WSOC. The notable reduction in the quantity of WSOC after 3 weeks to levels 2.5 times lower than pre-desiccation supports the role of microbial respiration in using the WSOC stored in streambed sediments (Schimel 2018) when alternative $\mathrm{C}$ sources like stream water are not available during non-flow periods. Thus, biogenic $\mathrm{CO}_{2}$ and $\mathrm{CH}_{4}$ fluxes observed during the first days of desiccation can translate to substantial sediment organic $\mathrm{C}$ mineralization. While rapid anaerobic decomposition of organic C could occur at early stages, including methanogenesis, aerobic respiration maintained during desiccation for prolonged time could additionally contribute to the decline of WSOC in dry sediments after 3 weeks. Enhanced respiration of sediment organic C associated with desiccation was also supported by the WSON results. The reduction of WSON (both in surface and deep sediments) as desiccation progressed indicates enhanced $\mathrm{N}$ mineralization pathways associated to the increase in $\mathrm{O}_{2}$, as recently outlined for dry riverbeds (Arce et al. 2018, 2019).

After 3 weeks of desiccation, the progressively decreasing $\mathrm{C}$ respiration led to relatively stable WSOC. A moderate increase of WSOC and WSON was detected after 6 weeks followed by a modest drop after 9 weeks. Certain imbalances in the relative importance of mechanisms acting as sink or source of the organic $\mathrm{C}$ sediment pool over prolonged desiccation could explain such fluctuations. There is evidence that drying-rewetting phenomena may drive the release of organic substrates from microbes through osmolysis (Fellman et al. 2011; Vázquez et al. 2011; Ylla et al. 2011). In combination with slow microbial activity, this would explain the increase in WSOC (and WSON) after 6 weeks. Conversely, the subsequent drop in WSOC after 9 weeks of desiccation could be associated to the fact that resistant microbes can quickly use this labile $\mathrm{C}$ fraction. The persistence of functional extracellular enzymes in desiccated sediments (Zoppini and Marxen 2011) may also have implications on WSOC quantity either by reducing concentrations through $\mathrm{C}$ mineralization (and $\mathrm{CO}_{2}$ production) or by contributing to the organic $\mathrm{C}$ pool themselves. 
Changes of organic matter quality provide evidence of the proposed mechanisms behind changes in WSOC. For instance, the contrasting developments of $\mathrm{SUVA}_{254}$ and WSOC over desiccation time revealed that organic matter in leachates became more aromatic at lower concentrations. This suggests microbial metabolism of labile compounds leading to accumulation of more recalcitrant, aromatic WSOC and WSON. Conversely, microbial contributions to the WSOC and WSON pool, presumably due to cellular lysis coupled to drying-rewetting, led to lower SUVA $_{254}$ values (Mavi and Marschner 2012). Insights that are more detailed are provided by size exclusion chromatography results, which identified dynamics of various organic matter fractions over desiccation time. While proportions of HS and LMWS appeared almost steady over desiccation, the proportion of HMWS in WSOC showed a drop that was significant after 6 weeks but further increased after 9 weeks. In parallel, a consistent decay was observed for WSON in this fraction. This finding confirms previous research in intermittent streams, where this fraction was found to be largely reactive in water (von Schiller et al. 2015; Catalán et al. 2017). The large HMWS fraction is mainly composed of biopolymers, but supramolecular assemblies formed by several individual compounds or dissolved organic matter bonded through weak forces may also contribute to this fraction (Piccolo et al. 2002; Kellerman 2015). The activity of exoenzymes (Zoppini and Marxen 2011) may particularly mediate biopolymer cleavage and loss of this organic matter fraction (Sinsabaugh and FollstadShah 2012). HMWS also exhibited a low C:N molar ratio, indicative of abundant nitrogen-containing proteins or amino sugars (Huber et al. 2011) and suggesting higher reactivity (von Schiller et al. 2015). Indeed, the observed progressively increasing C:N of HMWS may result from either a decrease in $\mathrm{N}$ (while $\mathrm{C}$ does not substantially vary) or otherwise, a supply of $\mathrm{C}$ (while $\mathrm{N}$ does not substantially vary). The proposed progressive cycles of microbial processing, including exoenzyme activity, and release of cellular compounds associated to water stress over desiccation, would explain such a trend of increasing $\mathrm{C}: \mathrm{N}$ ratio for HMWS. Together, the increased C:N ratio and the decline of HMWS strongly suggest preferential protein depolymerization (Reuter et al. 2020).
Comparison of experimental and field results

In-situ $\mathrm{CO}_{2}$ fluxes after 6 weeks of non-flow period $\left(234 \pm 21 \mathrm{mg} \mathrm{C} \mathrm{m}^{-2} \mathrm{~h}^{-1}\right.$, Table 1) were 3 times higher than measured in microcosms at comparable duration of desiccation $\left(75 \pm 16 \mathrm{mg} \mathrm{C} \mathrm{m}^{-2} \mathrm{~h}^{-1}\right)$. The high sediment humidity measured in the field at that time $(\mathrm{WC} \%=56$ and $42 \%$ in surface and deep sediments, respectively, Table 1) probably favored microbial respiration and $\mathrm{CO}_{2}$ production. In fact, microbial activity in dry streambeds may be maintained thanks to sporadic rainfalls, dew formation and the groundwater table buffering surface water loss (Harjung et al. 2019b; Gionchetta et al. 2019). Yet, anaerobic pathways (like $\mathrm{CH}_{4}$ production) are deactivated due to desiccation (Conrad et al. 2014), and although rainfall brings back inundated habitats in streambeds, the required low redox potential needed for methanogenic activity may require time to develop. Furthermore, unlike in our microcosms, terrestrial or airborne microbes may quickly colonize dry streambeds and compensate the loss of aquatic microbial diversity and activity caused by desiccation (Romaní et al. 2017).

Results from our in-situ assessment also suggest that as desiccation advances in time, there are substantial shifts in the quantity and quality of sediment $\mathrm{C}$ caused by sequential mineralization and release that comprise, respectively, a sink and a source of $\mathrm{C}$ stored in sediments. Nonetheless, we must consider that under natural conditions, accumulation of in-stream organic stocks (e.g. macrophytes, algae) and external inputs of leaf litter (Datry et al. 2018) can shape the quantity of $\mathrm{C}$ in streambed sediments. Such input explains that the OM\% in the surface sediment of the stream after 6 weeks of natural desiccation (mean $=29 \%$ ) was clearly higher than that observed in the microcosms (8\%) (Table 1). Consequently, WSOC in surface sediments was also larger in situ (0.18 $\mathrm{mg} \mathrm{C} \mathrm{g}^{-1} \mathrm{DM}$, Table 1) than in the microcosms at that time $\left(0.07 \mathrm{mg} \mathrm{C} \mathrm{g}^{-1} \mathrm{DM}\right)$.

Changes in $\mathrm{C}$ quality were also detected in the field after 6 weeks in comparison with the microcosms. While in microcosms the dominant WSOC fractions were HS, LMWS and HMWS respectively, LMWS was the dominant fraction in the field (Table 1), showing shifts in the bulk composition of WSOC towards a higher proportion of non-humic substances such as low molecular weight alcohols, aldehydes, 
ketones, sugars and amino acids (Huber et al. 2011). SUVA $_{254}$ showed values comparable to 6 weeks of experimental microcosms; yet, without reference values in the field before desiccation we cannot accurately evaluate the contribution of microbial processes to WSOC (and WSON) concentrations and composition. There is strong evidence of the importance of photodegradation during dry periods in intermittent streams (Dieter et al. 2013), which seems to enhance the decomposability of leaf litter (Datry et al. 2018; del Campo et al. 2021). Thus, this process, which did not happen in our experiment, may impose key changes in quality of $\mathrm{C}$ over desiccation beyond those we observed. Likewise, macroinvertebrates and terrestrial fungal decomposers on particulate organic matter may affect WSOC levels in the long run (Romaní et al. 2017). Yet, drying tends to reduce presence of macroinvertebrates (Schlief and Mutz 2009) and inhibit lignocellulolytic activity (MoraGómez et al. 2016). Thus, within a relatively short desiccation period, most changes in sediment organic matter rely on the WSOC fraction, with aquatic microbial communities still exhibiting $\mathrm{C}$ processing capacities.

Finally, we must note that differences between our field and laboratory results may also be at least partially due to the disturbance of the physical structure of the sediments used in the laboratory experiment during sampling.

\section{Conclusions}

Desiccation in intermittent streams boosts emissions of $\mathrm{CH}_{4}$ and mainly $\mathrm{CO}_{2}$ in the short term by favoring both physical evasion and aerobic mineralization. As drying progresses, these gaseous $\mathrm{C}$ fluxes decrease due to increasingly oxic conditions and water limitation. Rewetting in dry riverbeds does not always directly lead to flow recovery. Especially in temperate climates, a non-flow period can be frequently interrupted by sporadic rainfalls that can similarly trigger $\mathrm{C}$ cycling as described by the Birch effect in soils. Thus, rainfalls can rapidly trigger $\mathrm{CO}_{2}$ emissions fueled by WSOC from sediments and temporarily revert the desiccation impacts on biogenic $\mathrm{CO}_{2}$ production. The enhanced mineralization coupled to desiccation consequently shapes the role of sediments as a source and sink of organic $\mathrm{C}$ with a net tendency towards reducing in-stream organic loads as we found by the general drop in WSOC.

In intermittent streams, concentrations of the released substances may exceed baseflow values by several orders of magnitude and can thus substantially contribute to annual fluxes (Skoulikidis and Amaxidis 2009; Corti and Datry 2012; Bernal et al. 2013). We showed that desiccation can alter the quantity and quality of water-soluble organic matter, with important consequences for the organic matter released to the stream water upon rewetting. In the crucial moment of flow reestablishment (the so-called "first flush event"), material accumulated on the dry streambed is mobilized (Obermann et al. 2009; Corti and Datry 2012), and its reactivity may depend on the precedent preconditioning during the desiccation phase. Desiccation not only brings a cessation of stream water but also opens the door to other environmental drivers to operate within the dry streambed with more intensity than during flowing conditions. Processes such as photodegradation, terrestrial inputs of micro- and macro-biota to streambed as well as organic matter accumulation amplify with the lack of surface water, and their opportunity to impact $\mathrm{C}$ budgets will be clearly favored under long non-flow periods.

Collectively, our results support intermittent stream reaches as Ecosystem Control Points for C cycling within the stream network, with the duration of the dry phase exerting a strong control on this role. Further research that considers all mechanisms that operate in situ as desiccation progresses in time will surely complement our findings and improve our understanding of the biogeochemistry of intermittent streams.

Acknowledgements We thank Hoseung Jung for help in the field and in the laboratory. We also thank Anne Reinhard for support with the DNA extractions. This study was funded by the Alexander von Humboldt Foundation through a postdoctoral fellowship to MIA (Ref:1162886). MIA is also supported by the "Juan de la Cierva" research program of the Spanish Ministry of Science, Innovation and Universities (Ref: IJC2018-036969-I). DvS is a Serra Húnter Fellow.

Author contributions MIA, DvS and GS conceived and designed the experiment. Material preparation and data collection were performed by MIA and DZ. MMB, TU and JT analysed 16sRNA sequences. The first draft of the manuscript was written by MIA. All authors contributed to the development of the manuscript and read and approved the final version. All data, materials and software application supporting our published claims comply with field standards. Illumina MiSeq 
$16 \mathrm{~S}$ rRNA amplicon sequence data is submitted to the NCBI Short Read Archive (Accession No. SRP137655). Other datasets generated during and/or analyzed during the current study are available from the corresponding author on reasonable request.

Funding Open Access funding enabled and organized by Projekt DEAL. This study was funded by the Alexander von Humboldt Foundation through a postdoctoral fellowship to MIA (Ref:1162886). MIA is also supported by the "Juan de la Cierva" research program of the Spanish Ministry of Science, Innovation and Universities (Ref: IJC2018-036969-I). DvS is a Serra Húnter Fellow.

\section{Declarations}

Conflict of interest The authors have no conflicts of interest to declare that are relevant to the content of this article.

Open Access This article is licensed under a Creative Commons Attribution 4.0 International License, which permits use, sharing, adaptation, distribution and reproduction in any medium or format, as long as you give appropriate credit to the original author(s) and the source, provide a link to the Creative Commons licence, and indicate if changes were made. The images or other third party material in this article are included in the article's Creative Commons licence, unless indicated otherwise in a credit line to the material. If material is not included in the article's Creative Commons licence and your intended use is not permitted by statutory regulation or exceeds the permitted use, you will need to obtain permission directly from the copyright holder. To view a copy of this licence, visit http://creativecommons.org/licenses/by/4.0/.

\section{References}

Acuña V, Datry T, Marshall J et al (2014) Why should we care about temporary waterways? Science 343(6175):1080-1081. https://doi.org/10.1126/science. 1246666

Amalfitano S, Fazi S, Zoppini A et al (2008) Responses of Benthic Bacteria to Experimental Drying in Sediments from Mediterranean Temporary Rivers. Microb Ecol 55:270-279. https://doi.org/10.1007/s00248-007-9274-6

Andersen HE, Kronvang B, Larsen SE, Hoffmann CC, Jensen TS, Rasmussen EK (2006) Climate-change impacts on hydrology and nutrients in a Danish lowland river basin. Sci Total Environ 365(1):223-237. https://doi.org/10. 1016/j.scitotenv.2006.02.036

Arce MI, von Schiller D, Bengtsson MM, Hinze C, Jung H, Alves RJE, Urich T, Singer G (2018) Drying and rainfall shape the structure and functioning of nitrifying microbial communities in riverbed sediments. Front Microbiol 9:2794. https://doi.org/10.3389/fmicb.2018.02794

Arce MI, Mendoza-Lera C, Almagro M et al (2019) A conceptual framework for understanding the biogeochemistry of dry riverbeds through the lens of soil science. Earth Sci
Rev 188:441-453. https://doi.org/10.1016/j.earscirev. 2018.12.001

Bernal S, von Schiller D, Sabater F, Martí E (2013) Hydrological extremes modulate nutrient dynamics in mediterranean climate streams across different spatial scales. Hydrobiologia 719(1):31-42. https://doi.org/10.1007/s10750-0121246-2

Bernhardt ES, Blaszczak JR, Ficken CD et al (2017) Control points in ecosystems: moving beyond the hot spot hot moment concept. Ecosystems 20(4):665-682. https://doi. org/10.1007/s10021-016-0103-y

Birch HF (1958) The effect of soil drying on humus decomposition and nitrogen availability. Plant Soil 10:9-31. https:// doi.org/10.1007/BF01343734

Boulton AJ, Rolls RJ, Jaeger KL, Datry T (2017) Hydrological connectivity in intermittent rivers and ephemeral streams. In: Datry T, Bonada N, Boulton A (eds) Intermittent rivers and ephemeral streams. Academic Press, Massachusetts, pp 79-108

Callahan BJ, McMurdie PJ, Rosen MJ et al (2016) DADA2: high-resolution sample inference from Illumina amplicon data. Nat Methods 13(7):581-583. https://doi.org/10.1038/ nmeth.3869

Casas-Ruiz JP, Tittel J, von Schiller D et al (2016) Droughtinduced discontinuities in the source and degradation of dissolved organic matter in a Mediterranean river. Biogeochemistry 127(1):125-139. https://doi.org/10.1007/ s10533-015-0173-5

Catalán N, Casas-Ruiz JP, von Schiller D et al (2017) Biodegradation kinetics of dissolved organic matter chromatographic fractions in an intermittent river. J Geophys Res: Biogeosci 122(1):131-144. https://doi.org/10.1002/ 2016JG003512

Conrad R, Ji Y, Noll M, Klose M, Claus P, Enrich-Prast A (2014) Response of the methanogenic microbial communities in Amazonian oxbow lake sediments to desiccation stress. Environ Microbiol 16(6):1682-1694. https://doi. org/10.1111/1462-2920.12267

Corti R, Datry T (2012) Invertebrates and sestonic matter in an advancing wetted front travelling down a dry river bed (Albarine, France). Freshw Sci 31(4):1187-1201. https:// doi.org/10.1899/12-017.1

Dahm CN (1981) Pathways and mechanisms for removal of dissolved organic carbon from leaf leachate in streams. Can J Fish Aquat Sci 38(1):68-76. https://doi.org/10.1139/ f81-009

Datry T, Larned ST, Tockner K (2014) Intermittent rivers: a challenge for freshwater ecology. Bioscience 64(3):229-235. https://doi.org/10.1093/biosci/bit027

Datry T, Corti R, Foulquier A, von Schiller D, Tockner T (2016) One for all, all for one: a global river research network. EOS Earth Space Sci News 97(15):13-15

Datry T, Foulquier A, Corti R et al (2018) A global analysis of terrestrial plant litter dynamics in non-perennial waterways. Nat Geosci 11(7):497-503. https://doi.org/10.1038/ s41561-018-0134-4

del Campo R, Martí E, Bastias E, Barberá GG, Sanchez-Montoya MDM, Gómez R (2021) Floodplain preconditioning of leaf litter modulates the subsidy of terrestrial $\mathrm{C}$ and nutrients in fluvial ecosystems. Ecosystems 24:137-152. https://doi.org/10.1007/s10021-020-00508-5 
Dewey J, Hatten J, Choi B, Mangum C, Ouyang Y (2020) Climate drivers and sources of sediment and organic matter fluxes in intermittent rivers and ephemeral streams (IRES) of a Subtropical Watershed, USA. Climate 8(10):117. https://doi.org/10.3390/cli8100117

Dieter D, Frindte K, Krüger A, Wurzbacher C (2013) Preconditioning of leaves by solar radiation and anoxia affects microbial colonisation and rate of leaf mass loss in an intermittent stream. Freshw Biol 58(9):1918-1931. https:// doi.org/10.1111/fwb. 12180

Febria CM, Beddoes P, Fulthorpe RR, Williams DD (2012) Bacterial community dynamics in the hyporheic zone of an intermittent stream. ISME J 6:1078-1088. https://doi.org/ 10.1038/ismej.2011.173

Fellman JB, Dogramaci S, Skrzypek G, Dodson W, Grierson PF (2011) Hydrologic control of dissolved organic matter biogeochemistry in pools of a subtropical dryland river. Water Resour Res. https://doi.org/10.1029/ 2010WR010275

Fierer N, Schimel JP (2002) Effects of drying-rewetting frequency on soil carbon and nitrogen transformations. Soil Biol Biochem 34(6):777-787. https://doi.org/10.1016/ S0038-0717(02)00007-X

Fromin N, Pinay G, Montuelle B, Landais D, Ourcival JM, Joffre R, Lensi R (2010) Impact of seasonal sediment desiccation and rewetting on microbial processes involved in greenhouse gas emissions. Ecohydrology 3(3):339-348. https://doi.org/10.1002/eco.115

Gabor RS, Burns MA, Lee RH, Elg JB, Kemper CJ, Barnard HR, McKnight DM (2015) Influence of leaching solution and catchment location on the fluorescence of water-soluble organic matter. Environ Sci Technol 49(7):4425-4432. https://doi.org/10.1021/es504881t

Gallo EL, Lohse KA, Ferlin CM, Meixner T, Brooks PD (2014) Physical and biological controls on trace gas fluxes in semiarid urban ephemeral waterways. Biogeochemistry 121(1):189-207. https://doi.org/10.1007/s10533-0139927-0

Gebremichael A, Orr PJ, Osborne B (2019) The impact of wetting intensity on soil $\mathrm{CO}_{2}$ emissions from a coastal grassland ecosystem. Geoderma 343:86-96. https://doi. org/10.1016/j.geoderma.2019.02.016

Gionchetta G, Oliva F, Menéndez M, Laseras PL, Romaní AM (2019) Key role of streambed moisture and flash storms for microbial resistance and resilience to long-term drought. Freshw Biol 64(2):306-322. https://doi.org/10.1111/fwb. 13218

Gómez-Gener L, Obrador B, von Schiller D et al (2015) Hot spots for carbon emissions from Mediterranean fluvial networks during summer drought. Biogeochemistry 125(3):409-426. https://doi.org/10.1007/s10533-0150139-7

Gómez-Gener L, Obrador B, Marcé R et al (2016) When water vanishes: magnitude and regulation of carbon dioxide emissions from dry temporary streams. Ecosystems 19(4):710-723. https://doi.org/10.1007/s10021-016-99634

Graeber D, Gelbrecht J, Kronvang B, Gücker B, Pusch MT, Zwirnmann E (2012) Technical Note: Comparison between a direct and the standard, indirect method for dissolved organic nitrogen determination in freshwater environments with high dissolved inorganic nitrogen concentrations. Biogeosciences 9(11):4873-4884. https://doi. org/10.5194/bg-9-4873-2012

Harjung A, Ejarque E, Battin T, Butturini A, Sabater F, Stadler M, Schelker J (2019a) Experimental evidence reveals impact of drought periods on dissolved organic matter quality and ecosystem metabolism in subalpine streams. Limnol Oceanogr 64(1):46-60. https://doi.org/10.5194/bg8-1539-2011

Harjung A, Perujo N, Butturini A, Romaní AM, Sabater F (2019) Responses of microbial activity in hyporheic pore water to biogeochemical changes in a drying headwater stream. Freshw Biol 64(4):735-749. https://doi.org/10. 1111/fwb. 13258

Heinz M, Zak D (2018) Storage effects on quantity and composition of dissolved organic carbon and nitrogen of lake water, leaf leachate and peat soil water. Water Res 130:98-104. https://doi.org/10.1016/j.watres.2017.11.053

Huber SA, Balz A, Abert M, Pronk W (2011) Characterisation of aquatic humic and non-humic matter with size-exclusion chromatography-organic carbon detection-organic nitrogen detection (LC-OCD-OND). Water Res 45(2):879-885. https://doi.org/10.1016/j.watres.2010.09.023

Huson DH, Auch AF, Qi J, Schuster SC (2007) MEGAN analysis of metagenomic data. Genome Res 17(3):377-386

Jin H, Yoon TK, Lee SH, Kang H, Im J, Park JH (2016) Enhanced greenhouse gas emission from exposed sediments along a hydroelectric reservoir during an extreme drought event. Environ Res Lett 11:124003. https://doi. org/10.1088/1748-9326/11/12/124003

Keller PS, Catalán N, von Schiller D et al (2020) Global $\mathrm{CO}_{2}$ emissions from dry inland waters share common drivers across ecosystems. Nat Commun 1:2126. https://doi.org/ 10.1038/s41467-020-15929-y

Kellerman AM (2015) Molecular-level dissolved organic matter dynamics in lakes: constraints on reactivity and persistence. Dissertation, University of Uppsala

Kim DG, Vargas R, Bond-Lamberty B, Turetsky MR (2012) Effects of soil rewetting and thawing on soil gas fluxes: a review of current literature and suggestions for future research. Biogeosciences 9:2459-2483. https://doi.org/10. 5194/bg-9-2459-2012

Koschorreck M (2000) Methane turnover in exposed sediments of an Amazon floodplain lake. Biogeochemistry 50:195-206. https://doi.org/10.1023/A:1006326018597

Kosten S, van den Berg S, Mendonça R, Paranaíba JR, Roland F, Sobek S, van den Hoek J, Barros N (2018) Extreme drought boosts $\mathrm{CO}_{2}$ and $\mathrm{CH}_{4}$ emissions from reservoir drawdown areas. Inland waters 8(3):329-340. https://doi.org/10.1080/ 20442041.2018.1483126

Lanzén A, Jorgensen SL, Bengtsson MM, Jonassen I, Øvreås L, Urich T (2011) Exploring the composition and diversity of microbial communities at the Jan Mayen hydrothermal vent field using RNA and DNA. FEMS Microbiol Ecol 77(3):577-589. https://doi.org/10.1111/j.1574-6941.2011. 01138.x

Lanzén A, Jorgensen SL, Huson DH et al (2012) CREST classification resources for environmental sequence tags. PLoS One 7:e49334. doi:https://doi.org/10.1371/journal. pone.0049334 
Looman A, Maher DT, Pendall E, Bass A, Santos IR (2017) The carbon dioxide evasion cycle of an intermittent first-order stream: contrasting water-air and soil-air exchange. Biogeochemistry 132:87-102. https://doi.org/10.1007/ s10533-016-0289-2

Louca S, Parfrey LW, Doebeli M (2016) Decoupling function and taxonomy in the global ocean microbiome. Science 353(6305):1272-1277. doi:https://doi.org/10.1126/ science.aaf 4507

Marcé R, Obrador B, Gómez-Gener L, Catalán N, Koschorreck M, Arce MI, Singer G, von Schiller D (2019) Emissions from dry inland waters are a blind spot in the global carbon cycle. Earth Sci Rev 188:240-248. https://doi.org/10.1016/ j.earscirev.2018.11.012

Mavi MS, Marschner P (2012) Drying and wetting in saline and saline-sodic soils - effects on microbial activity, biomass and dissolved organic carbon. Plant Soil 355(1):51-62. doi. https://doi.org/10.1007/s11104-011-1078-2

McClain ME, Boyer EW, Dent CL et al (2003) Biogeochemical hot spots and hot moments at the interface of terrestrial and aquatic ecosystems. Ecosystems 6:301-312. https://doi. org/10.1007/s10021-003-0161-9

McMaster D, Bond N (2008) A field and experimental study on the tolerances of fish to Eucalyptus camaldulensis leachate and low dissolved oxygen concentrations. J N Am Benthol Soc 59(2):177-185. https://doi.org/10.1071/MF07140

McNamara CJ, Leff LG (2004) Bacterial community composition in biofilms on leaves in a northeastern Ohio stream. J N Am Benthol Soc 23(4):677-685.

Messager ML, Lehner B, Cockburn C et al (2021) Global prevalence of non-perennial rivers and streams. Nature 594:391-397. https://doi.org/10.1038/s41586-021-035655

Mora-Gómez J, Elosegi A, Duarte S, Cássio F, Pascoal C, Romaní AM (2016) Differences in the sensitivity of fungi and bacteria to season and invertebrates affect leaf litter decomposition in a Mediterranean stream. FEMS Microbiol Ecol 92(8):fiw121. https://doi.org/10.1093/femsec/ fiw 121

Muñoz I, Abril M, Casas-Ruiz JP, Casellas M, Gómez-Gener L, Marcé R, Menéndez M, Obrador B, Sabater S, von Schiller D, Acuña V (2018) Does the severity of non-flow periods influence ecosystem structure and function of temporary streams? A mesocosm study. Freshwater Biol 63(7):613-625. https://doi.org/10.1111/fwb.13098

Nützmann G, Mey S (2007) Model-based estimation of runoff changes in a small lowland watershed of north-eastern Germany. J Hydrol 334(3-4):467-476. https://doi.org/10. 1016/j.jhydrol.2006.10.026

Obermann M, Rosenwinkel KH, Tournoud MG (2009) Investigation of first flushes in a medium-sized mediterranean catchment. J Hydrol 373(3-4):405-415. https://doi.org/10. 1016/j.jhydrol.2009.04.038

Obrador B, von Schiller D, Marcé R, Gómez-Gener L, Koschorreck M, Borrego C, Catalán N (2018) Dry habitats sustain high $\mathrm{CO}_{2}$ emissions from temporary ponds across seasons. Sci Rep 8(1):1-12. https://doi.org/10.1038/ s41598-018-20969-y

Placella SA, Brodie EL, Firestone MK (2012) Rainfall-induced carbon dioxide pulses result from sequential resuscitation of phylogenetically clustered microbial groups. Proc Natl
Acad Sci USA 109(27):10931-10936. https://doi.org/10. 1073/pnas.1204306109

Piccolo A, Conte P, Trivellone E, van Lagen B, Buurman P (2002) Reduced heterogeneity of a lignite humic acid by preparative HPSEC following interaction with an organic acid. Characterization of size-separates by Pyr-GC-MS and 1H-NMR spectroscopy. Environ Sci Technol 36(1):76-84. https://doi.org/10.1021/es010981v

Pinto RMS, Weigelhofer G, Diaz-Pines E, Brito AG, Zechmeister-Boltenstern S, Hein T (2020) River-floodplain restoration and hydrological effects on GHG emissions: biogeochemical dynamics in the parafluvial zone. Sci Total Environ 715:136980. https://doi.org/10.1016/j.scitotenv. 2020.136980

Pohlon E, Rütz NK, Ekschmitt K, Marxsen J (2018) Recovery dynamics of prokaryotes and extracellular enzymes during sediment rewetting after desiccation. Hydrobiologia 820(1):255-266. https://doi.org/10.1007/s10750-018$3662-4$

Prosser JI (2012) Ecosystem processes and interactions in a morass of diversity. FEMS Microbiol Ecol 81(3):507-519. https://doi.org/10.1111/j.1574-6941.2012.01435.x

Raymond PA, Saiers JE, Sobczak WV (2016) Hydrological and biogeochemical controls on watershed dissolved organic matter transport: Pulse-shunt concept. Ecology 97(1):5-16. https://doi.org/10.1890/14-1684.1

Reuter H, Gensel J, Elvert M, Zak D (2020) Evidence for preferential protein depolymerization in wetland soils in response to external nitrogen availability provided by a novel FTIR routine. Biogeosciences 17:499-514. https:// doi.org/10.5194/bg-17-499-2020

Romaní AM, Chauvet E, Febria C, Mora-Gómez J, Risse-Buhl U, Timoner X, Weitere M, Zeglin L (2017) The biota of intermittent rivers and ephemeral streams: prokaryotes, fungi, and protozoans. In: Datry T, Bonada N, Boulton A (eds) Intermittent rivers and ephemeral streams. Academic Press, Massachusetts, pp 161-188

Sabater S, Tockner K (2010) Effects of hydrologic alterations on the ecological quality of river ecosystems. In: Sabater S, Barceló D (eds) Water scarcity in the Mediterranean. The handbook of environmental chemistry. Springer, Berlin. https://doi.org/10.1007/698_2009_24

Schimel J, Becerra CA, Blankinship J (2017) Estimating decay dynamics for enzyme activities in soils from different ecosystems. Soil Biol Biochem 114:5-11. https://doi.org/ 10.1016/j.soilbio.2017.06.023

Schimel JP (2018) Life in dry soils: effects of drought on soil microbial communities and processes. Annu Rev Ecol Evol Syst 49:409-432. https://doi.org/10.1146/annurev-ecolsys110617-062614

Schlief J, Mutz M (2007) Response of aquatic leaf associated microbial communities to elevated leachate DOC: a microcosm study. Int Rev Hydrobiol 92(2):146-155. https://doi.org/10.1002/iroh.200510950

Schlief J, Mutz M (2009) Effect of sudden flow reduction on the decomposition of alder leaves (Alnus glutinosa [L.] Gaertn.) in a temperate lowland stream: a mesocosm study. Hydrobiologia 624(1):205-217. https://doi.org/10.1007/ s10750-008-9694-4

Shumilova O, Zak D, Datry T et al (2019) Simulating rewetting events in intermittent rivers and ephemeral streams: a 
global analysis of leached nutrients and organic matter. Glob Change Biol 25(5):1591-1611. https://doi.org/10. 1111/gcb.14537

Sinsabaugh RL, Follstad Shah JJ (2012) Ecoenzymatic stoichiometry and ecological theory. Annu Rev Ecol Evol Syst 43:313-343. https://doi.org/10.1146/annurev-ecolsys071112-124414

Skoulikidis N, Amaxidis Y (2009) Origin and dynamics of dissolved and particulate nutrients in a minimally disturbed Mediterranean river with intermittent flow. J Hydrol 373:218-229. https://doi.org/10.1016/j.jhydrol.2009.04. 032

Sponseller RA (2007) Precipitation pulses and soil $\mathrm{CO}_{2}$ flux in a Sonoran Desert ecosystem. Glob Change Biol 13(2):426-436. https://doi.org/10.1111/j.1365-2486.2006. 01307.x

Tao S, Lin B (2000) Water soluble organic carbon and its measurement in soil and sediment. Water Res 34(5):1751-1755. https://doi.org/10.1016/S00431354(99)00324-3

Thompson LR, Sanders JG, Mcdonald D et al (2017) A communal catalogue reveals Earth's multiscale microbial diversity. Nature. https://doi.org/10.1038/nature24621

Vázquez E, Amalfitano S, Fazi S, Butturini A (2011) Dissolved organic matter composition in a fragmented Mediterranean fluvial system under severe drought conditions. Biogeochemistry 102(1):59-72. https://doi.org/10.1007/s10533010-9421-x

Vidal-Abarca MR, Gómez R, Sánchez-Montoya MM, Arce MI, Nicolás N, Suárez ML (2020) Defining dry rivers as the most extreme type of non-perennial fluvial ecosystems. Sustainability 12(17):7202. https://doi.org/10.3390/ su12177202

von Schiller D, Marcé R, Obrador B, Gómez-Gener L, CasasRuiz JP, Acuña V, Koschorreck M (2014) Carbon dioxide emissions from dry watercourses. Inland waters 4(4):377-382. https://doi.org/10.5268/IW-4.4.746

von Schiller D, Graeber D, Ribot M, Timoner X, Acuña V, Martí E, Sabater S, Tockner K (2015) Hydrological transitions drive dissolved organic matter quantity and composition in a temporary Mediterranean stream. Biogeochemistry 123(3):429-446. https://doi.org/10.1007/s10533-0150077-4 von Schiller D, Bernal S, Dahm CN, Martí E (2017) Nutrient and organic matter dynamics in intermittent rivers and ephemeral streams. In: Datry T, Bonada N, Boulton A (eds) Intermittent rivers and ephemeral streams. Academic Press, Massachusetts, pp 135-160

von Schiller D, Datry T, Corti R et al (2019) Sediment respiration pulses in intermittent rivers and ephemeral streams. Glob Biogeochem Cycles 33(10):1251-1263. https://doi. org/10.1029/2019GB006276

Walters W, Hyde ER, Berg-Lyons D et al (2016) Improved bacterial 16S rRNA gene (V4 and V4-5) and fungal internal transcribed spacer marker gene primers for microbial community surveys. mSystems 1(1):e00009e15. doi:10.1128/ mSystems.00009-15

Wang H, Lu J, Wang W, Yang L, Yin C (2006) Methane fluxes from the littoral zone of hypereutrophic Taihu Lake, China. J Geophys Res 111:D17. https://doi.org/10.1029/ 2005JD006864

Weishaar JL, Aiken GR, Bergamaschi BA, Fram MS, Fujii R, Mopper K (2003) Evaluation of specific ultraviolet absorbance as an indicator of the chemical composition and reactivity of dissolved organic carbon. Environ Sci Technol 37(20):4702-4708. https://doi.org/10.1021/es030360x

Wilkinson J, Bors C, Burgis F, Lorke A, Bodmer P (2018) Measuring $\mathrm{CO}_{2}$ and $\mathrm{CH}_{4}$ with a portable gas analyzer: closed-loop operation, optimization and assessment. PLoS ONE 13(4):e0193973. https://doi.org/10.1371/journal. pone. 0193973

Ylla I, Sanpera-Calbet I, Muñoz I, Romaní AM, Sabater S (2011) Organic matter characteristics in a Mediterranean stream through amino acid composition: changes driven by intermittency. Aquat Sci 73(4):523-535. https://doi.org/ 10.1007/s00027-011-0211-x

Zoppini A, Marxsen J (2010) Importance of extracellular enzymes for biogeochemical processes in temporary river sediments during fluctuating dry-wet conditions. In: Shukla G, Varma A (eds) Soil enzymology. Soil biology. Springer, Berlin. https://doi.org/10.1007/978-3-64214225-3_6

Publisher's Note Springer Nature remains neutral with regard to jurisdictional claims in published maps and institutional affiliations. 